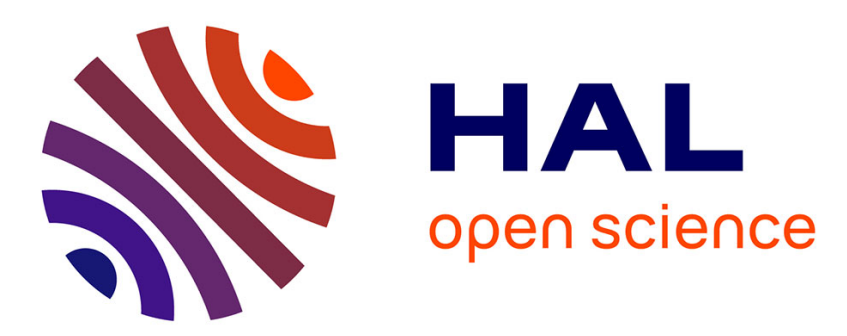

\title{
Modelling pesticides transfer to surface water at the catchment scale: a multi-criteria analysis \\ Payraudeau, Gregoire
}

\section{To cite this version:}

Payraudeau, Gregoire. Modelling pesticides transfer to surface water at the catchment scale: a multicriteria analysis. Agronomy for Sustainable Development, 2012, 32 (2), pp.479-500. 10.1007/s13593011-0023-3 . hal-00930492

\section{HAL Id: hal-00930492 https://hal.science/hal-00930492}

Submitted on 1 Jan 2012

HAL is a multi-disciplinary open access archive for the deposit and dissemination of scientific research documents, whether they are published or not. The documents may come from teaching and research institutions in France or abroad, or from public or private research centers.
L'archive ouverte pluridisciplinaire HAL, est destinée au dépôt et à la diffusion de documents scientifiques de niveau recherche, publiés ou non, émanant des établissements d'enseignement et de recherche français ou étrangers, des laboratoires publics ou privés. 


\title{
Modelling pesticides transfer to surface water at the catchment scale: a multi-criteria analysis
}

\author{
Sylvain Payraudeau • Caroline Gregoire
}

Accepted: 4 January 2011 / Published online: 29 April 2011

(C) INRA and Springer Science+Business Media B.V. 2011

\begin{abstract}
The demand for operational tools at a catchment scale is growing to assess both the sustainability of agricultural practices and the efficiency of mitigation measures on pesticide transfer to surface water. Here a literature review of 286 investigations highlights the large number of indicators and hydrochemical models developed at the catchment scale. Given this large number of indicators and models, the choice is difficult for potential users. Therefore, this article proposes a multi-criteria analysis applied to ten existing tools including physically based and conceptual models, indicators and multi-agent systems. We found the following major points: (1) Indicators and conceptual models are the most popular approaches to assess the transfer of pesticides to surface water at the catchment scale due to a trade-off between environmental relevance and adaptation to user's needs. (2) The latest indicators developed are inferred from the results of conceptual or physically based models to combine the strengths of each approach. (3) Only a handful of physically based models have addressed both flow and pesticide transport at the catchment as affected by the internal heterogeneity of the system. However, it is only physically based models that can simulate the impact of changes to the catchment. Physically based models integrate feedbacks between hydrological and chemical processes not possible from conceptual models or indicators alone. (4) The ability of models to assess the pesticide loads both in the dissolved and particulate phases is a key issue not properly addressed by many indicators or models. A key way forward is the
\end{abstract}

\footnotetext{
S. Payraudeau $(\bowtie) \cdot$ C. Gregoire

Laboratory of Hydrology and Geochemistry of Strasbourg

(LHyGeS), University of Strasbourg/ENGEES, CNRS,

1 quai Koch BP 61039 F,

67070 Strasbourg cedex, France

e-mail: sylvain.payraudeau@engees.unistra.fr
}

integration of erosion processes with the fate of pesticide adsorbed to these particles. (5) At the catchment, the hydrological connectivity is perhaps the primary hydrological variable required to correctly assess rapid flow processes as surface runoff and associated pesticide transfer. This in turn implies using tools that explicitly represent the connectedness of surface and/or sub-surface water pathways including mitigation measures to correctly assess the risk of pesticide transfer.

Keywords Pesticides · Surface water - Hydrological connectivity · Processes · Models · Catchment · Watershed . Review $\cdot$ Evaluation · Uncertainty

\section{Contents}

1. Introduction $\ldots \ldots \ldots \ldots \ldots \ldots \ldots \ldots$

2. Outline of the review ............ 3

2.1 A literature survey . . . . . . . . . . . . . . . . . .

2.2 Physically based models . . . . . . . . . . . . . . . . . . .

2.3 Conceptual models . . . . . . . . . . . . . . . . . . . . . . . . . . . . .

2.4 Indicators . . . . . . . . . . . . . . . . . . . . . . .

2.5 Multi-Agent Systems . . . . . . . . . . . . . . . . . . . . .

2.6 Conclusions . . . . . . . . . . . . . . . . . . .

3. Comparison of models based on six selected criteria . . 6

3.1 Intended users and objectives . . . . . . . . . 6

3.2 Model applicability, scale and temporal resolution . $\ldots \ldots \ldots \ldots \ldots \ldots \ldots \ldots \ldots \ldots$. . . . . . . . . .

3.3 Including hydrological processes and fate of pesticide in models . . . . . . . . . . . 10

3.4 Required data and examples of application . . . . 13

3.5 Evaluation of models . . . . . . . . . . . 15

3.6 Sensitivity and uncertainty analyses . . . . . . 16

4. Conclusion . . . . . . . . . . . . . . 18 


\section{Introduction}

The use of fertilizer and pesticides has contributed to an increase in yields. However, contamination of surface water (Brady et al. 2006) and groundwater (Gooddy et al. 2002) has increased over the last decades. Consequently, research has focused on the various constraints and key components of pesticides transfer in different environmental compartments, such as the atmosphere (Gil and Sinfort 2005), groundwater (Bloomfield et al. 2006; Arias-Estevez et al. 2008), surface water (Fiener et al. 2005; Gregoire et al. 2010; Holvoet et al. 2007; Moore et al. 2006; Schriever et al. 2007), in particular rivers and lakes (Du Preez et al. 2005; Konstantinou et al. 2006), the soil (Andreu and Picó 2004; Corwin and Loague 2004; Reichenberger et al. 2007), irrigated fields (Müller et al. 2007), natural (Williams 2002; Mitsch and Gosselink 2007) or artificial wetlands (Moore et al. 2001; Rose et al. 2006; Dordio et al. 2007), as well as urban areas (Blanchoud et al. 2007).

The mechanisms of transfer of pesticides are governed by a combination of hydrological, chemical and microbiological processes (Pell and Stenström 2004; Gavrilescu 2005). The relative importance of these processes varies over time and scale, ranging in size from the research plot to field size and up to the catchment (Campbell and Garrido 2004 ; Poissant et al. 2008). The pesticide fluxes generated within an agrosystem are governed by the movement of water and the hydrologic and hydraulic characteristics of the catchment. Pesticide persistence in soil and fluxes are also related to rainfall (Ramwell et al. 2002), in particular the intensity of the rainfall event (Pot et al. 2005; McGrath et al. 2008, 2010).

Therefore, it appears relevant to focus on the catchment scale in order to better define the relationship between the source of pollution and the hydrologic and hydraulic characteristics of the catchment, when protection of regional water resources is the objective (Joannon et al. 2005). Additionally, evaluating the environmental risk at the scale of catchment that constitutes the hydrological functional unit (Finizio and Villa 2002) and an "action" scale (Wauchope 2005) is a crucial issue due to increasing concern of consumers as well as farmers and chemical companies with respect to the approval procedures for new compounds and drinking water standards (Hamilton et al. 2003). Analysing the offsite movement of pesticides assumes the identification and quantification of the various pesticide transfer pathways and degradation processes from the application point, e.g. the field or the group of fields in agricultural areas (Leu et al. 2004a), to the endpoint (Faria et al. 2007). Agricultural fields are often in contact with terrestrial ecosystems such as field edges or hedges, or integrated in aquatic ecosystems such as ditches, rivers, wetlands or ponds (Kolditz et al. 2007). Pesticide transfer and degradation processes are relatively well defined at the scale of the cultivated field (Moreby and Southway 1999; Bedos et al.
2002, 2006), or of the experimental plot (Delphin and Chapot 2006) even if more knowledge is needed to improve the assessment of pesticides risks at this scale (Alletto et al. 2010). Most of the modelling efforts are restricted to edge-of-field type calculations. The field-scale pesticide-runoff-leaching indicators and models have been steadily improving with European projects such as PEGASE (Mouvet et al. 2004) and FOOTPRINT (Dubus et al. 2007) to assess the pesticide transfer at different scales from the farm to European Union. However, pesticide transfer and degradation processes are not well defined at the catchment scale due to the spatial and temporal variability of the processes that affect the fate and transport of pesticides (Louchart et al. 2001; Leu et al. 2004b). One of the main difficulties to assess the pesticide transfer at the catchment scale is both to correctly take into account the catchment heterogeneity, which cannot be completely known or described (Durand et al. 2002) and the hydrological connectivity between the site where pesticides have been applied and the ground and surface water (Frey et al. 2009). Indeed, hydrological connectivity especially for surface runoff is characterized by a substantial spatiotemporal variability depending of characteristic rainfall patterns, soil properties and landscape components such as hedges, ditches or road network (Ambroise 2004; Ocampo et al. 2006; Lehmann et al. 2007).

Several models have been developed in order to enable a quantitative evaluation of the offsite movement of pesticides as well as an evaluation of pesticide exposure of aquatic organisms. The term "model" is used in the broad sense of a simplified representation of a system and its functioning. It corresponds here to a simplified representation of pesticide transfer and degradation processes. We focus then on the hydrochemical models and on the indicators. The differences between hydrochemical models and indicators can be difficult to distinguish (Stenrød et al. 2008). The models rely on a combination between different but complementary fields, including agronomy, hydrology, physicochemistry, biochemistry and cognitive sciences (Henriksen et al. 2007).

Though several review papers comparing modelling approach of pesticide fate in a general sense are available, they do not unequivocally integrate the catchment scale as an analysis criterion excepted in Borah and Bera (2004), Quilbe et al. (2006) and Holvoet et al. (2007). Review papers have been mostly focused on (a) a specific group of models, such as leaching models at the soil column or agricultural field scale (Vanclooster et al. 2000; Siimes and Kämäri 2003; Jantunen et al. 2004; Alvarez-Benedi et al. 2004; Köhne et al. 2009), (b) several types of models designed by a particular institution such as the Agricultural Research Service (Wauchope et al. 2003), (c) indicators of risk exposure or pesticide contamination (Reus et al. 2002; Devillers et al. 2005) at the regional or farm scale (Halberg et al. 2005), (d) regional and national spatialization of the simulation's results of the 1D leaching models MACRO, 
PEARL or PRZM such as GeoPearl or FitoMarche (Sood and Bhagat 2005; Tiktak et al. 2006; Balderacchi et al. 2008; Pavlis et al. 2010) or (e) a cross-analysis of different models of pesticide fate and the environmental indicators to underscore their relative strengths, weaknesses, similarities and dissimilarities (Dubus and Surdyk 2006).

Several criteria determine the choice of the appropriate approach to enable an environmental evaluation with respect to the transfer of pesticides within a catchment. This review paper introduces, clarifies and organises into a hierarchy these criteria and focuses on organic pesticides. The overall goal of this paper is then to identify the various existing models of pesticide transfer to surface water at the catchment scale, in a nonexhaustive but representative manner by identifying the main approaches, including the physically based and conceptual modelling, indicators, as well as multi-agents modelling (Bousquet and Le Page 2004). First, we describe the various types of existing models at the catchment scale. Second, we study the relevance of such modelling approaches based on a multi-criteria approach that includes the expressed objectives, the potential users, the theoretical concepts used to perform the processes, the transfer pathways and selected degradation processes, the integration of the spatiotemporal variability of these processes, the method used to evaluate the model reliability and the incorporation of uncertainties propagation. For each type of approach, an example of application is provided at the catchment scale in order to illustrate the required data for each type of models analysed in this review. The examples of application, located in the western Europe (France and Belgium), allow to cover a large range of climate, e.g. Mediterranean and oceanic, soil types and agricultural types. The common point of all the selected models is to provide an assessment of the pesticide transfer to surface water at the catchment scale by taking into account the hydrological connectivity between fields to catchment's outlet with varying degree of complexity. The leaching models were not analysed here. Indeed, rapid flow processes as surface runoff required to correctly assess the impact of pesticide transfer to surface water. These processes can be difficult to properly integrate into the structure of a leaching model (Jantunen et al. 2004; Trevisan and Vischetti 2004) without coupling with hydrological models (Christiansen et al. 2004; Luo and Zhang 2009). This analysis is followed by some recommendations to facilitate the choice of a model to assess the risks related to pesticide transfer to surface water as a function of the selected criteria, at the scale of the catchment.

\section{Outline of the review}

The purpose of this review is to examine relevant criteria for choosing a modelling approach to assess pesticides transfer to surface water at the catchment scale. Ten candidate models have been selected (MIKE SHE ADM, LEACHM-runoff, GR5pesticides, SACADEAU, SWAT, STREAM-pesticide, FLOWT, VESPP, I-Phy-Bvci and PHYLOU; Table 1). These models illustrate four main modelling approaches: (a) physically based modelling, (b) conceptual modelling, (c) indicators and (d) multi-agents modelling. The ten selected models are analysed according to six key criteria, namely (a) the objectives

Table 1 Model types and case studies used for the analysis and comparison of available pesticide fate tools at the catchment scale

\begin{tabular}{|c|c|c|c|}
\hline Model type & Model name & Case studies references & Objectives and scope \\
\hline \multirow[t]{4}{*}{ Type 1: physically based model } & MIKE SHE ADM & $\begin{array}{l}\text { De Bruyn 2004; } \\
\text { De Bruyn et al. } 2006\end{array}$ & $\begin{array}{l}\text { Hydrological modelling in order to mechanistically represent the karstic } \\
\text { aquifers and the fate of point and non-point source pollution }\end{array}$ \\
\hline & LEACHM-runoff & Maison 2000 & $\begin{array}{l}\text { Hydrological modelling in order to mechanistically represent the } \\
\text { quantitative and qualitative regime of the catchment }\end{array}$ \\
\hline & GR5-pesticides & Madier 2007 & $\begin{array}{l}\text { Using a pesticide fate model to define robust sampling strategies with } \\
\text { reduced cost, i.e. with a minimum of analyses }\end{array}$ \\
\hline & SACADEAU & $\begin{array}{l}\text { Tortrat 2005; Gascuel- } \\
\text { Odoux et al. } 2009\end{array}$ & $\begin{array}{l}\text { Building a decision-aid tool to help specialists in charge of the } \\
\text { catchment's management to preserve the stream water quality }\end{array}$ \\
\hline \multirow[t]{3}{*}{ Type 2: conceptual model } & SWAT & Holvoet et al. $2005 ; 2008$ & $\begin{array}{l}\text { Modelling the impact of land management practices on water and } \\
\text { pesticide loads in large catchments with varying soils, land uses and } \\
\text { management conditions over long time periods }\end{array}$ \\
\hline & $\begin{array}{l}\text { STREAM- } \\
\text { pesticides }\end{array}$ & Lecomte 1999 & $\begin{array}{l}\text { Modelling the behaviour of pesticides driven by runoff and erosion from } \\
\text { the cultivated plots to the catchment area }\end{array}$ \\
\hline & FLOWT & $\begin{array}{l}\text { Gregoire 2006; } \\
\text { Madier } 2007\end{array}$ & $\begin{array}{l}\text { Modelling the impact of land management practices on water and } \\
\text { pesticide loads in small catchments with varying soils, land uses } \\
\text { and management conditions over long time periods }\end{array}$ \\
\hline \multirow[t]{2}{*}{ Type 3: environmental indicator } & VESPP & De Bruyn 2004; 2006 & Evaluating the vulnerability of surface water to pesticides \\
\hline & I-Phy-BVci & Thiollet-Scholtus 2004 & Evaluating the vulnerability of surface water to pesticides \\
\hline Type 4: multi-agent system & PHYLOU & $\begin{array}{l}\text { Barreteau and } \\
\text { Cernesson } 2003\end{array}$ & $\begin{array}{l}\text { Facilitate communication between stakeholders by using an agent-based } \\
\text { model of pesticide transfer in order to preserve the stream water quality }\end{array}$ \\
\hline
\end{tabular}


and potential users, (b) the domain of definition and the boundary conditions in terms of spatial scale and temporal dynamics, (c) the simplification and conceptualisation of pesticide transfer processes, (d) the required data, (e) the type of model evaluation and (f) the ability to perform a sensitivity analysis on input parameters and associate an uncertainty with the results.

\subsection{A literature survey}

A literature survey was performed in the scientific database ISI Web of Science to analyse the diversity of modelling approaches assessing the pesticide transfer on surface water at the catchment scale. Since 1975, 286 studies are listed in ISI Web of Science database. Catchment-scale pesticide runoff assessment methods emerged in the 1980s (Fig. 1) while field-scale assessment methods emerged in the 1960s (Wauchope 1978). As highlighted by Wohlfahrt et al. (2010), this may be due to the fact that fieldprocess understanding and modelling is a prerequisite to a catchment scale view. The specificities of the four modelling approaches, i.e. physically based and conceptual models, indicators and multi-agent systems are detailed in the Sections 2.2 to 2.5 .

\subsection{Physically based models}

This type of model uses state variables, e.g. water content, that are mutually dependent by state relationships, including dynamic relationships (linking fluxes of matter to gradient of potentials and resistance of the medium) and conservation relationships (balances of matter, energy, quantity and momentum). After establishment of the initial and boundary conditions, physically based models simulate the system at each point and time step of a fine spatiotemporal gridding. The distributed (or spatialized) aspect means that the model explicitly takes into account the spatial variability of the parameters, the processes and the boundary conditions of the system. The hydrological connectivity between agricultural fields and the groundwater table or the hydrological network is thus implicitly taken into account in the different equations of the model. The purpose of investigating this family of models is to obtain a tool, which only requires measurable parameters to enable extrapolation to noninstrumented catchment with similar characteristics. Within the context of developing management tools, only physically based models may be used to simulate changes to the system (i.e. variation in the land use or practices). Indeed, the knowledge and consideration of the spatial distribution of processes in the model are essential because the impact of a particular action will vary as a function of its location in the catchment (Vieux 1991). In the current generation of physically based hydrological models, a variety of approaches has been used to couple surface and subsurface flow processes at the processes, whereas as showed by the Fig. 1, only a handful of models have addressed both flow and transport (Therrien et al. 2005; Weill et al. 2010). To illustrate the advantages and limits of this family of models, we detailed two examples integrating pesticide transport (Table 1): LEACHM-runoff (Maison 2000) and MIKE SHE ADM (De Bruyn 2004; De Bruyn et al. 2006).

\subsection{Conceptual models}

Conceptual hydrological models and their associated pesticide modules rely on the simplification of processes regarding the water cycle and the fate of pesticides. The literature survey
Fig. 1 Temporal evolution of studies assessing pesticide transfer on surface water at the catchment scale with physically based and conceptual models, indicator and multi-agent systems $(n=14,93,170$ and 9, respectively, search term combination in ISI Web of Science: (indicator* and pesticide* or multi* and agent* and water* and pollut* or model* and pesticide* or indicator* and pesticide* or pesticide* and watershed*) within title, keywords and abstract coupled with a systematic analysis of the relevance of the papers) during the last 36 years. The number of studies for 2010 is preliminary result limited to the access date 28 October 2010

\section{Number of studies}

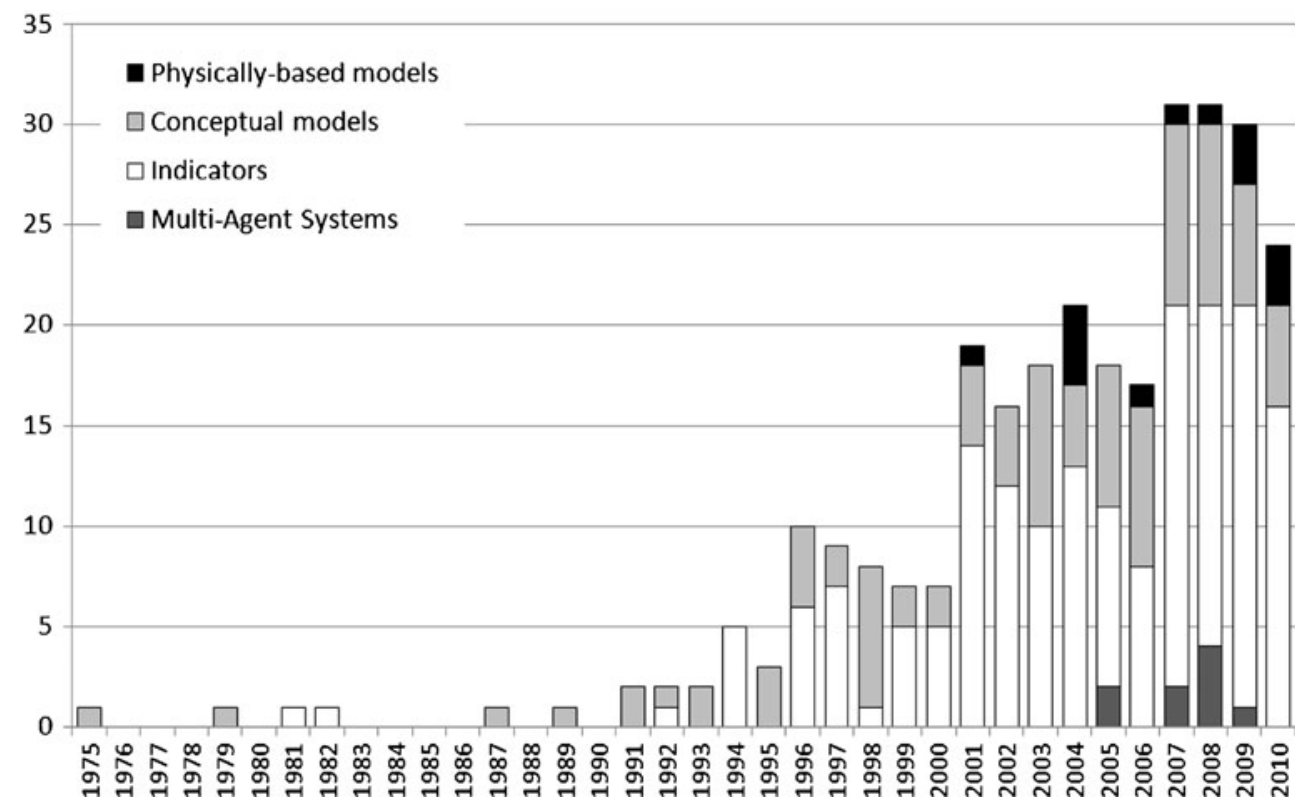


reveals a diversity of approaches within this family of models with 93 different studies accounting for 33\% of the studies between 1975 and 2010 (Fig. 1). The hydrological functioning of the catchment is divided into a series of interconnected reservoirs that are "homogenous" with respect to the physical characteristics and/or to the hydrological functioning. These models can be called lumped model if the catchment is considered as a unique entity. The global model GR5 illustrates this sub-family in this review paper (Table 1). The catchment can also be split up in units considered as "homogeneous" with respect to the physical characteristics and/or to the hydrological functioning. Each unit is thus represented by a series of reservoirs and no more the entire catchment. This structure allows considering the spatial distribution of the hydrological characteristics of each unit and the input variables. Hence, the representation of the hydrological connectivity between the fields and the surface and ground water is performed for each unit. Depending of the maturity of a model, the border between conceptual and physically based models can be difficult to distinguish. Some existing conceptual models can be improved by removing simplifying assumptions and adding physically based hydraulic processes and chemical reactions (Joyce et al. 2010). Four examples allow to illustrate the diversity of the representation of the fate of pesticide within this family (Table 1): SACADEAU (Tortrat 2005; Gascuel-Odoux et al. 2009), SWAT (Holvoet et al. 2005, 2008), STREAM-pesticide (Lecomte 1999) and FLOWT (Gregoire 2006; Madier 2007).

\subsection{Indicators}

An "indicator is a variable which supplies information on other variables which are difficult to access or measure (...) and can be used as a benchmark to make decisions" (Gras et al. 1989) and is an "alternative measure (...) which is a tool to gain an understanding of a complex system (...) so that effective management decisions can be made that lead towards the stated objectives" (Mitchell et al. 1995).

Indicators constitute the basis of various methods used for the evaluation of the environmental impact of land-use practices. They help with the prediction and understanding of the impact of an agricultural system on the environmental according to the initial setup and objectives (IISD 1997). Use of indicators overcomes difficulties related to obtaining direct measurements due to methodical difficulties, practical reasons, costs or duration of the data acquisition (Bockstaller and Girardin 2003) and may explain the large number of indicators developed since the 1980s accounting for $59 \%$ of the studies between 1975 and 2010 (Fig. 1). If a risk of impact is predictable, indicators generally characterize a risk of exposure to water masses (Finizio and Villa 2002); however, the risk of impact on the organisms is more difficult to characterize. The number of factors used in the construction of exposure indicators is highly variable
(Devillers et al. 2005). The use of results of hydrochemical models in the calculation of indicators, such as the PESTLA model and the EYP indicator (Reus et al. 2002) or the MHYDAS model and a pesticide transport indicator (Wohlfahrt et al. 2010), illustrates the difficulty to distinguish the border between indicators and hydrochemical models. The representation of hydrological connectivity in an indicator can be inferred from the results of a hydrochemical model (Wohlfahrt et al. 2010). These results are combined into a synthetic indicator according soil types, soil management, pesticides and climatic scenario database. Even if development of this type of indicator requires large number of simulations, the synthetic indicator can be easily use in the decision-making process as a way to locating risky areas and comparing different scenarios in water-quality management.

Two indicators of exposure VESPP (De Bruyn 2004, 2006) and I-Phy-BVci (Thiollet-Scholtus 2004) are analysed in this review in order to identify the advantages and limits of this family of tools (Table 1).

\subsection{Multi-agent systems}

The objective of multi-agents systems as applied to the environmental field is to understand and model the impact of the actors, including their relationships, on natural resource, such as the water quantity and/or quality (Bousquet and Le Page 2004). These tools are used within the context of the pesticides problem in order to understand the impact and the adaptability of each stakeholder with respect to the quantities of pesticides that can be transferred at the outlet of the catchment (Houdart 2005; Houdart et al. 2009). The main objective is thus to correctly represent the pesticides transfer pathways and the magnitude of fluxes. Consequently, these tools include a representation of processes whose complexity varies as a function of the type of model for the fate of pesticide. The effort in modelling focuses on the causal relationships between modalities of the agricultural practices (type of molecule, application frequency, date of application), the role of pesticide mitigation structures (vegetated strips, artificial wetlands) and the fate of pesticides. Only a handful of multi-agent systems are dedicated to the pesticide transfer at the catchment scale (Fig. 1). The tool PHYLOU (Barreteau and Cernesson 2003) illustrates the particularities of the kind of tool (Table 1).

\subsection{Conclusions}

In terms of the number of studies, indicators and conceptual models are the most popular approaches to assess the transfer of pesticides to surface water at the catchment scale (Fig. 1), accounting for $59 \%$ and $33 \%$ of the studies, respectively. 
The four approaches considered in the review paper diverge with respect to:

- The degree to which the complexity of the processes are simulated and the nature of the relationships used to described them (from the conceptual to the physically based models)

- Their respective capacity to reproduce the potential or observed concentration or loads in surface water (from the indicators to the conceptual or physically based models)

- Their respective capacity to take into account more or less accurately the decision rules and the agricultural practices of the farmers (from the multi-agents systems to the conceptual or physically based models)

\section{Comparison of models based on six selected criteria}

Various model classifications have been proposed to help a user select the model most suitable for a specific objective (Jantunen et al. 2004; Quilbe et al. 2006). The originality of the proposed typology is to combine the criteria proposed for leaching models by Jantunen et al. (2004) and for hydrochemical models by Quilbe et al. (2006).

The uniqueness and similarities of the four approaches presented above is discussed based on ten examples of models, while considering the following six criteria: (a) the intended users and objectives; (b) model applicability, scale and temporal resolution; (c) degree of simplification of hydrological and pesticide fate processes; (d) the required data; (e) model evaluation and (f) consideration of data uncertainty and parameter sensitivity analysis.

\subsection{Intended users and objectives}

All the models analysed in this paper directly originate from research efforts, in more or less relationships with the farming profession. The objectives vary according to the model type (Table 1). The authors of physically based models have the objective to use their models for research and to improve process understanding. However, their implementation requires a level of understanding, which limits their use outside of the field of research (MIKE SHE ADM and LEACH-runoff; Table 2). Conceptual hydrochemical models are theoretically more user-friendly, as they are less-demanding in terms of data and computation time. However, their implementation generally requires a calibration phase implying the availability of water and pesticides concentration and load data. Finally, the skills required for using these tools limit their implementation by the stakeholders (Table 2). Environmental indicators are by definition more user-friendly as they provide an overall picture enabling a diagnostic and proposals of actions. However, their environmental relevance, i.e. their capacity to determine the impact of agricultural practices, should be checked (Payraudeau and van der Werf 2005). The final users of these indicators can be the various stakeholders who are responsible for waterquality management of a catchment; these include the farmer' advisors and other policy makers (Table 2). The multi-agents approach is the only model that directly associates the farmers without intermediates such as the farmers' advisors (Table 2). The objective of this model is to increase the level of awareness of the stakeholders regarding the environmental consequences of practices that involve the use of pesticides. These tools particularly aim at providing qualitative results allowing an appropriation by the stakeholders of the predominating processes as well as a hierarchical listing of on-farm practices in order of the greatest potential for environmental harm.

Chemical firms are identified as potential users of conceptual or physically based models at the scale of the catchment (Table 2). In practice, models for the fate of pesticides when used in approval procedures are very often 1-D models operating at the field scale which can be applied at the catchment scale (Trevisan and Vischetti 2004) or regional and national scales (Tiktak et al. 2006; Balderacchi et al. 2008; Pavlis et al. 2010). Hence, the objectives of these models are to determine the potential risks of transfer to surface and groundwater for various soil types, climates and agricultural
Table 2 Intended (letter $\mathrm{X}$ in italics) and effective (letter $X$ in bold) users of the described models of the pesticides fate

\begin{tabular}{|c|c|c|c|c|c|}
\hline & Farmers & Farmer advisors & Policy makers & Chemical firms & Researchers \\
\hline MIKE SHE ADM (type 1) & & & $X$ & & $\mathbf{X}$ \\
\hline LEACHM-runoff (type 1) & & & $X$ & & $\mathbf{x}$ \\
\hline GR5-pesticides (type 2) & & & $X$ & & $\mathbf{x}$ \\
\hline SACADEAU (type 2) & & $\mathbf{x}$ & & & $\mathbf{x}$ \\
\hline SWAT (type 2) & & & $\mathbf{X}$ & $X$ & $\mathbf{X}$ \\
\hline STREAM-pesticide (type 2) & & $X$ & & & $\mathbf{x}$ \\
\hline FLOWT (type 2) & & & & & $\mathbf{x}$ \\
\hline VESPP (type 3) & & $\mathbf{x}$ & & & $\mathbf{x}$ \\
\hline I-Phy-Bvci (type 3) & & $\mathbf{x}$ & $\mathbf{x}$ & & $\mathbf{x}$ \\
\hline PHYLOU (type 4) & $\mathbf{X}$ & $\mathbf{x}$ & $\mathbf{x}$ & & $\mathbf{x}$ \\
\hline
\end{tabular}


practices. Consequently, a specific model applied to a specific catchment cannot be included within the pesticide approval procedure.

The criterion of potential users is thus highly discriminating as it determines the success of the modelling procedure according to the addressed objectives (Table 1). The use of a too complex model may lead to a rejection by some stakeholders who do not have the necessary scientific understanding/skills. Conversely, the use of a qualitative model does not give specific results such as if a water-body will meet drinking water standards. The use of models belonging to different modelling approaches in the same catchment can be a solution that benefits from their respective advantages. However, it remains rare to use more than two approaches on the same catchment. For example, such work has been performed for the VESPP indicators and the physically based model MIKE SHE ADM (De Bruyn 2004, 2006), as well as for the lumped conceptual model GR5-pesticides and the spatialized conceptual model FLOWT (Madier 2007).

\subsection{Model applicability, scale and temporal resolution}

The choice of a model for the fate of pesticide assumes matching the objective of the study (Table 1), the characteristics of the study site and the application domain of the model (Table 3). Most of the models can be applied in various climatic contexts. However, the assumptions inherent in each model, in particular those used to describe the key process of runoff, limit the global applicability of the models and care must be used when matching a model with a particular catchment or objective. Thus, models that condition the surface runoff to an excess of the soil infiltration capacity, such as PHYLOU, are more adapted to the Mediterranean catchment, which have no permanent flow and thus are not permanently connected to an adjacent groundwater system (Table 3). Conversely, considering the hydrological connectivity between surface and groundwater in the calculation of the discharge, such as in the SACADEAU model, generally restricts the application to the oceanic context usually characterized by permanent connection between surface water and adjacent groundwater system (Table 3). The models generally present a relationship between the range of the area considered in the modelled catchments and the time step of the input data, including the rainfall and the output variables of the model. Thus, models that are adapted to large catchments from about ten to about a hundred square kilometres, whose response time is a day or more, rely on input and output data at a daily time step, e.g. SWAT. Conversely, models adapted to smaller catchment whose area ranges from a few hectares to a few square kilometres (Table 3 ) generally rely on input data at a minute time step (GR5-pesticides, STREAM-pesticide, FLOWT, PHYLOU) to an hourly time step (SACADEAU). The dynamics of pesticide fluxes can be captured by the models from the infra-hour time step (FLOWT, GR5-pesticide), accumulated at the scale of the runoff event (STREAMpesticide, I-PHY-Bvci) or year (VESPP). With the exception of the lumped model GR5-pesticide, all the selected models present a distributed approach of the catchment (Table 3).

The discretization can rely on a regular grid in two dimensions for the conceptual models and the indicators (SACADEAU, STREAM-pesticide, VESPP, PHYLOU), or in three dimensions for the physically based models (MIKE SHE ADM, LEACHM-runoff). A discretization relying on homogenous units in terms of hydrological functioning is also possible (Table 3). This discretization can integrate field delineation (FLOWT, I-PHY-BVci) or not (SWAT). Some models display a mixed segmentation of the space encompassing both a grid to represent the level of the water table and homogeneous units to spatialize the inputs of pesticides (SACADEAU). Considering the type of agriculture (Table 3), the parameterization of some models relies on the decision rules exclusively adapted to the vineyard catchments (FLOWT, I-PHY-BVci and PLYLOU), large-scale crop (STREAM-pesticide) or bocage landscapes (SACADEAU). The adaptation of a model to other hydroclimatic or cropping patterns usually includes intensive work on the hypotheses and on the structure of the model. Analysing the adequacy between the application domain of a model and the catchment under investigation is a crucial criterion to avoid a failure of the modelling process. Indeed, a model that is employed out of its application domain can provide fair results for some variables, such as runoff volumes, but may lead to an erroneous representation of the water transfer pathways (Beven 2002). In order to choose the correct model for an application, an understanding of the hydrology and chemistry of the catchment as well as an understanding of the strengths and weaknesses of a particular model is needed.

\subsection{Including hydrological processes and fate of pesticide in models}

Simulating the fate of a pesticide requires a simplification of the water and pesticide cycles. At the scale of the catchment, these cycles concern five environmental compartments, namely the atmosphere, plant, soil (unsaturated zone), groundwater and surface water (perennial stream, ponds and lakes). Forty-two processes have been listed from an analysis of the ten models (Table 4). The term "process" refers here to a separate step in the water cycle or pesticide fate. The processes have been grouped by environmental compartment, i.e. atmosphere, plant, soil and water. Diversity of the modelling approaches originates from the inclusion or not of these different processes. None of the ten models includes the entire set of 42 processes. The number of processes taken into account varies from 


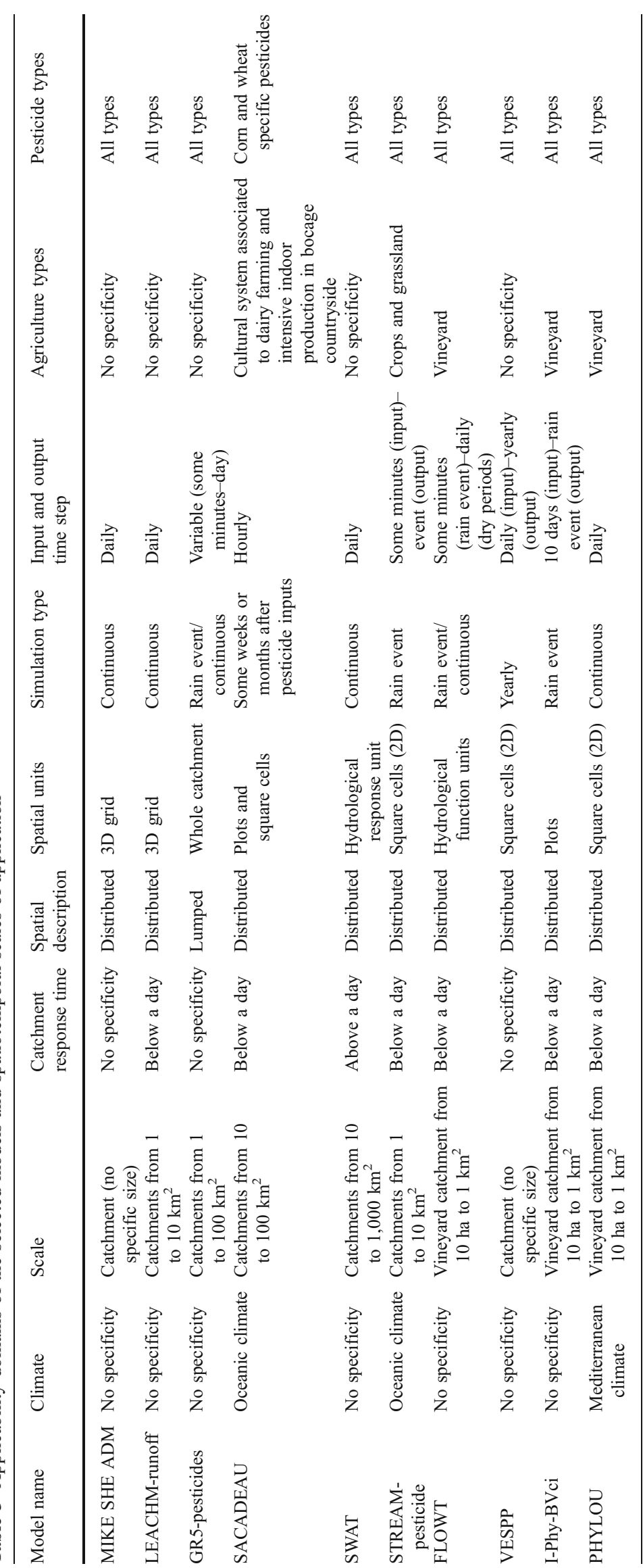


Table 4 Hydrological and pesticide fate processes in air, plant and soil compartments taken into account in the studied models and the selected models

\begin{tabular}{|c|c|c|c|c|c|c|c|c|c|}
\hline Processes & $\begin{array}{l}\text { MIKE SHE } \\
\text { ADM }\end{array}$ & $\begin{array}{l}\text { LEACHM- } \\
\text { runoff }\end{array}$ & $\begin{array}{l}\text { GR5- } \\
\text { pesticides }\end{array}$ & SACADEAU & SWAT & $\begin{array}{l}\text { STREAM- } \\
\text { pesticide }\end{array}$ & FLOWT & VESPP & $\begin{array}{l}\text { I-Phy- PHYLOU } \\
\text { BVci }\end{array}$ \\
\hline
\end{tabular}

Air

Drift

Deposition

Plant

Plant growth

Water cycle

Interception

Foliar evaporation

Roots uptakes

Pesticide fate

Volatilisation

Washoff

Degradation

Soil (unsaturated zone)

Water cycle

Horton runoff

Saturation excess runoff

Infiltration

Evaporation

Percolation

Lateral sub-surface flow

Capillary fringe

Fate of dissolved pesticides

Soil/water exchanges

Advection/dispersion

Degradation

Volatilisation

Fate of particular pesticides

Erosion

Deposition on vegetated strips

Aquifer

Water cycle

Flows

River/aquifer exchanges

$\mathrm{X}$

Pesticide fate

Volatilisation

Advection/dispersion

Adsorption

Degradation

River

Water cycle

Flows

Pesticide fate

Deposition

Resuspension

Volatilisation

Advection/dispersion

Degradation

Landscape mitigation objects
X

X

$\mathrm{X}$

$\mathrm{X}$

$\mathrm{X}$

$\mathrm{X}$

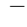

$-$

$-$

$\mathrm{X}$

$\mathrm{X}$

$\mathrm{X}$

$\mathrm{X}$

$\mathrm{X}$

$\mathrm{X}$

$\mathrm{X}$

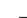

$\mathrm{X}-\mathrm{X}$

X

X X

X

$\mathrm{X}$ 
Table 4 (continued)

\begin{tabular}{|c|c|c|c|c|c|c|c|c|c|c|}
\hline Processes & $\begin{array}{l}\text { MIKE SHE } \\
\text { ADM }\end{array}$ & $\begin{array}{l}\text { LEACHM- } \\
\text { runoff }\end{array}$ & $\begin{array}{l}\text { GR5- } \\
\text { pesticides }\end{array}$ & SACADEAU & SWAT & $\begin{array}{l}\text { STREAM- } \\
\text { pesticide }\end{array}$ & FLOWT & VESPP & $\begin{array}{l}\text { I-Phy- } \\
\text { BVci }\end{array}$ & PHYLOU \\
\hline \multicolumn{11}{|l|}{ Vegetated ditch } \\
\hline Degradation & - & - & - & - & - & - & - & $\mathrm{X}$ & - & - \\
\hline \multicolumn{11}{|l|}{ Grass strips } \\
\hline Infiltration & - & - & - & $\mathrm{X}$ & - & $\mathrm{X}$ & $\mathrm{X}$ & $\mathrm{X}$ & & \\
\hline Degradation & - & - & - & - & $\mathrm{X}$ & - & - & $\mathrm{X}$ & $\mathrm{X}$ & $\mathrm{X}$ \\
\hline \multicolumn{11}{|l|}{ Wetlands } \\
\hline Degradation & - & - & - & - & - & - & - & - & $\mathrm{X}$ & - \\
\hline Ponds, lakes & - & - & - & - & & & & & & \\
\hline Deposition & - & - & - & - & $\mathrm{X}$ & - & - & - & - & - \\
\hline Resuspension & - & - & - & - & $\mathrm{X}$ & - & - & - & - & - \\
\hline Volatilisation & - & - & - & - & $\mathrm{X}$ & - & - & - & - & - \\
\hline Advection/dispersion & - & - & - & - & $\mathrm{X}$ & - & - & - & - & - \\
\hline Degradation & - & - & - & - & $\mathrm{X}$ & - & - & - & - & - \\
\hline Number of processes & 21 & 11 & 9 & 13 & 32 & 8 & 8 & 7 & 12 & 8 \\
\hline
\end{tabular}

seven (VESPP) to 32 (SWAT), with an average of about ten processes. Several factors can explain this variation.

First, the models have an application domain that may include or not various environmental compartments. Thus, the physically based model LEACHM-runoff that has been designed based on the Auradé catchment (Table 5), characterized by the absence of permanent river network and the low contribution of groundwater to the surface water dynamic, only includes 11 processes (Table 4). The other representative of this family, MIKE SHE ADM, has 21 processes, including those in the saturated zone and in river processes (Table 4). These last two compartments cannot be neglected when modelling larger catchments.

Second, most models begin life in a fairly simplified form, i.e. many processes are simulated with simplified assumptions, but then through time or because of a need these simplified assumptions are replaced with more realistic models of the processes. For instance, the conceptual model SWAT includes 32 processes and appears as the most comprehensive model representing the water and pesticide cycles. It displays a significant degree of maturity by associating several models that had been separately validated in the various environmental compartments (Wauchope et al. 2003): EPIC for the plant growth, CREAMS for the hydrology, GLEAMS for the fate of pesticides and SWRRB for the extension of the application field at the catchment scale. More simplified models such as Stream-pesticide, FLOWT and SACADEAU have been improved to enhance the applicability domain, and their authors have already identified the next processes to be integrated into future versions.
Finally, the various approaches rely on a number of processes that are adapted to the particular objectives (Table 1). Physically based and conceptual hydrochemical models aim at reproducing the discharges, piezometric levels and pesticide concentration values. Thus, they include a significant number of processes, ranging from eight for FLOWT to 32 for SWAT. Conversely, indicator models aim at producing more overall information by selecting major processes, ranging from seven for VESPP to 12 for I-Phy-Bvci. Event-based hydrochemical models, such as GR5-pesticides, STREAM-pesticide, and FLOWT, do not include the evapotranspiration or degradation processes, which are assumed to be negligible with respect to the response time of the catchments (Table 3). The exemplified multi-agent systems approach (PHYLOU; Table 1) is intermediate with a simplified representation of the pesticide fate and water cycle that includes eight processes (Table 4).

The analysis of the described compartments shows a substantial heterogeneity. Among the ten models examined within this paper, the indicator model I-Phy-Bvci is the only model that integrates the atmospheric compartment, notably the influence of treatment practices in terms of the quantity available at the plant or soil surfaces. The soil compartment is the most completely covered compartment across the ten models with a minimum of three process (Horton runoff, infiltration, and volatilization) or (Horton runoff/soil water exchanges and degradation) for I-Phy-Bvci and VESPP, respectively, and a maximum of 11 of 13 processes for the SWAT model (Table 4). 


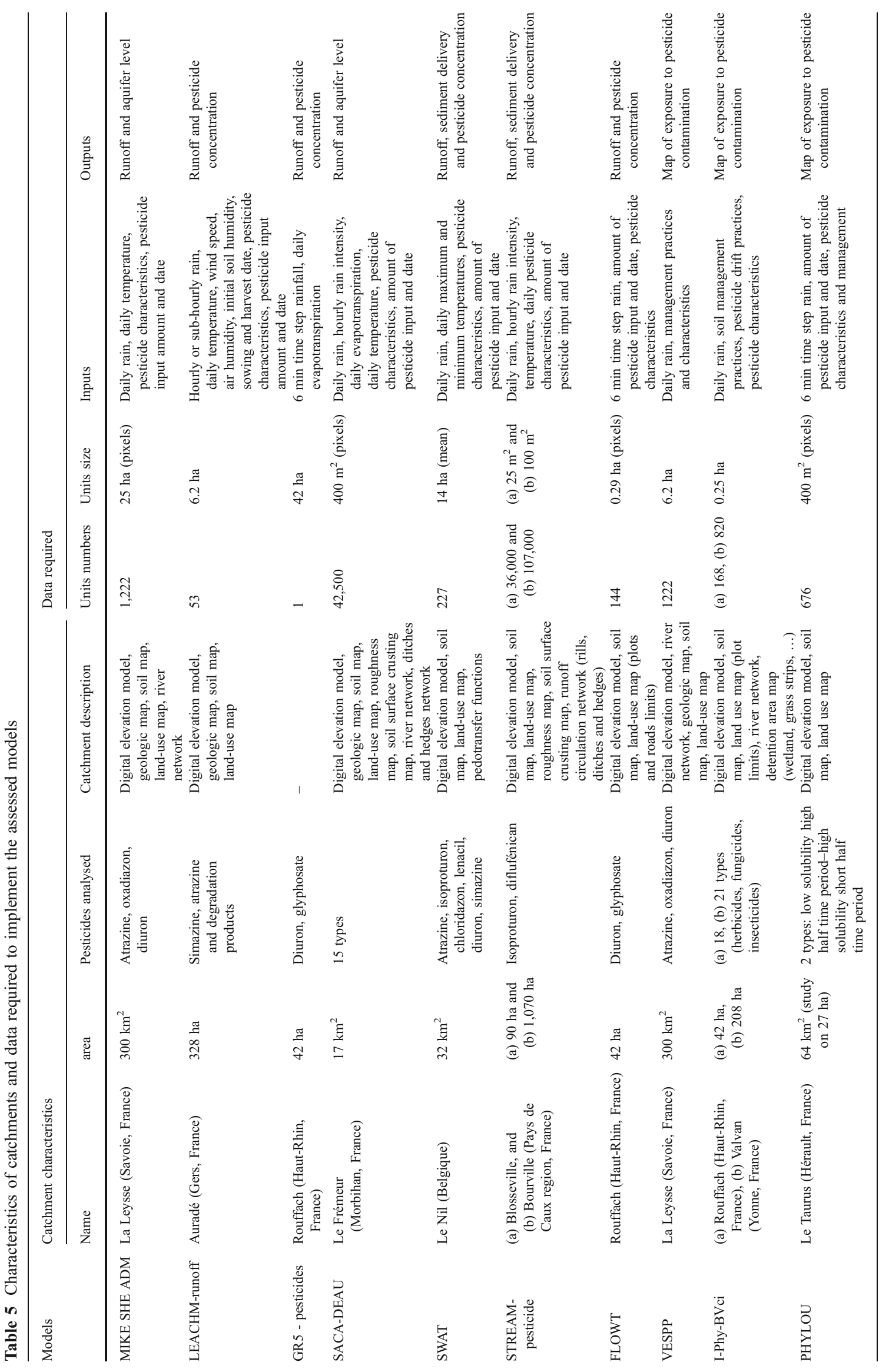


The plant growth processes is in all models with the exception of GR-pesticides, VESPP and PHYLOU models. The SWAT model has all of the processes listed for this compartment (Table 4). The GR5-pesticides model excludes any processes from this compartment completely. However, the integration of the plant compartment is important as it determines the degree of soil covering and changes over a temporal scale the runoff and erosion properties within the models.

Processes intervening at the soil surface or within the soil (Table 4) are systematically represented, independently if they represent the water cycle or the fate of pesticide in the dissolved phase. How a particular process is represented may differ between models for example the process of infiltration/runoff. This is important as this process determines the apportionment of the water and pesticide flux between the surface and ground water. All the models simulate the runoff as an excess of the infiltration capacity. Physically based models use the Richard's equation to represent the water flux within the soil, the change in water content and the infiltration capacity of the soil, either in one dimension (MIKE SHE $\mathrm{ADM})$ or in two dimensions (LEACHM-runoff). The diversity of the concepts used within the conceptual models to represent the runoff is very high. The SWAT model uses either the curve number approach of the Soil Conservation Service, or the one-dimension Green and Ampt equation. The GR5-pesticides model uses a reservoir to represent the evolution of the soil water storage capacities. The FLOWT model uses the Horton equation to determine the runoff to infiltration ratio. The STREAMpesticide and SACADEAU models rely on the use of experts rules that determine the runoff/infiltration ratio related to the condition of the soil surface. The indicator models indirectly include the runoff to infiltration ratio by characterizing the risk of runoff either exclusively as a function of the vegetation cover, the slope and the soil cultivation (VESPP), or while additionally integrating the soil texture (I-Phy-Bvci). Only MIKE SHE ADM and SACADEAU integrate the saturation excess runoff. Saturation excess runoff typically occurs at the base of hillslopes, where soil moisture is high due to downslope movement of sub-surface water in soils with impermeable horizons or on impermeable rock, where a perched water table develops, and in areas of shallow groundwater.

The integration of the erosion processes and the fate of pesticide attached to particles add an additional degree of complexity. Consequently, the number of modes integrating these processes is small. Among the ten models, only SWAT and STREAM-pesticide integrate the fate of the sorbed pesticides (Table 4). This can be explained by the limited ability to models to correctly integrate the erosion processes (Jetten et al. 2003; Takken et al. 2005) and the fate of pesticide sorbed to particles (Alletto et al. 2010). Therefore, a key way forward is the integration of erosion processes with the fate of pesticide adsorbed to these particles (Borggaard and Gimsing 2008; Pesce et al. 2010). From a practical perspective, processes occurring in the saturated zone are only taken into account in the model developed on the catchment that has a water table close to the surface (SACADEAU) or for application domain larger than about ten square kilometres (MIKE SHE ADM, GR5-pesticides, SWAT; Table 3). The same observation can be made for the river compartment, which only concerns catchments larger than a few square kilometres and with perennial streams.

Finally, the use of mitigation measures to limit pesticide transfer is highly variable within the ten models (Table 4). The effect of the vegetated strips is often simulated by locally increasing the infiltration and optionally the pesticide degradation rate (Table 4). Vegetated ditches only appear in the VESPP indicator. The potential pesticide degradation within the wetland areas (Gregoire et al. 2009) is only simulated in the I-Phy-Bvci model. The role played by water surfaces, i.e. lakes, ponds, in the fate of pesticides is represented as a module within the SWAT model. Among the ten models, the role of these mitigation measures is perceived as essential for setting up indicators of risk only in the conceptual models. The ability to take into account mitigation measures was previously retained as a key point to assess impact of best management practices (Quilbe et al. 2006). The physically based models focused on the water cycle and pesticide fate do not include such measures (Table 4). The weakness of the studied models to take into account the mitigation measures can be explained by the difficulty of obtaining relevant data on pesticide remediation efficiency for each type of mitigation measure (Reichenberger et al. 2007). More knowledge of pesticide mitigation is needed to correctly integrate these measures into models. The European project ArtWET (Gregoire et al. 2009) has thus generated data on the efficiency of artificial wetlands that will be rapidly integrated into existing models such as FOOTPRINT models (Dubus et al. 2007).

The adequacy between the observed functioning of the catchment and the simplification degree of the model in terms of processes and compartments is an inescapable criterion. Beyond the represented processes (Table 4), the choice of the model should integrate the target objectives (Table 1) and the applicability domain of the model (Table 3), itself depending on the various represented processes (Table 4). At the scale of the catchment, the hydrological connectivity (Fig. 2), i.e. the connection between the fields and the hydrologic network or groundwater, cannot be neglected to correctly assess rapid flow processes as surface runoff (Ambroise 
Fig. 2 Spatial and temporal variation of the hydrological connectivity between fields and outlet of a catchment (a without connectivity for low intensity rainfall event; b with connectivity during high intensity rainfall event)

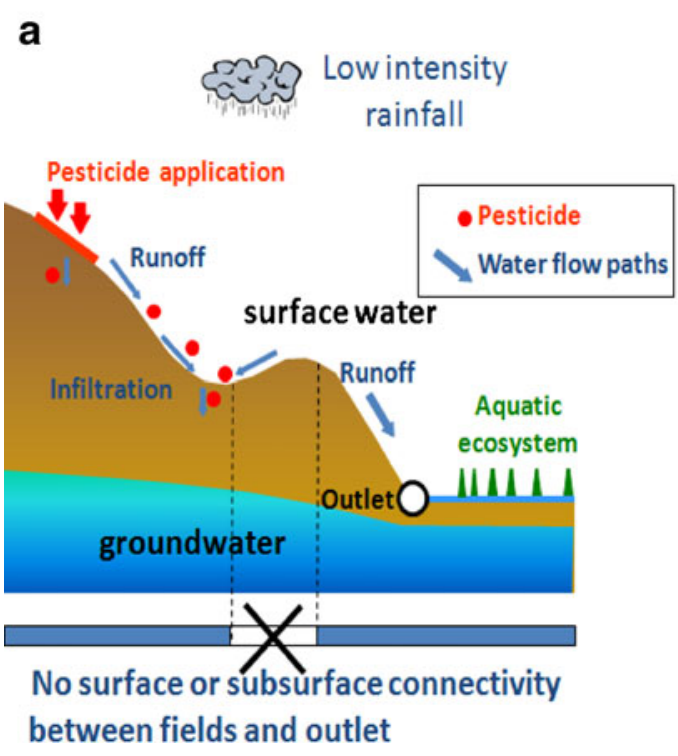

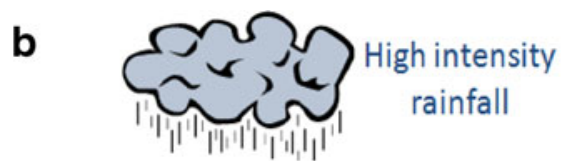

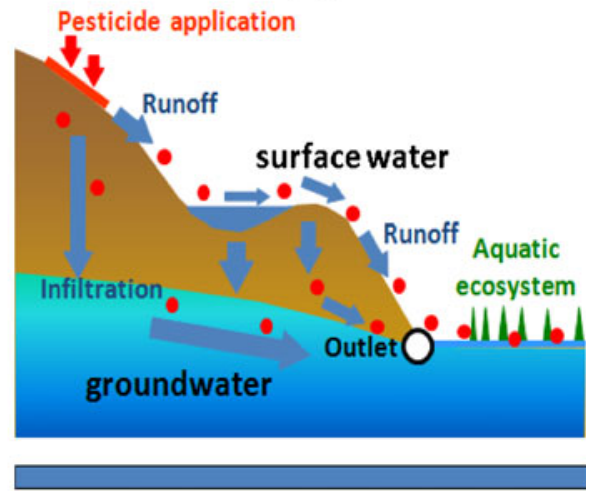

Surface and/or subsurface connectivity between fields and outlet
2004; Ocampo et al. 2006) and associated pesticide transfer. A detailed integration of the connectivity at the catchment scale is crucial to distinguish the active areas, i.e. generating runoff, from areas that effectively contribute to the discharge at the outlet. A disconnected field, i. e. with no hydrological connectivity from field to catchment outlet, should not contribute to the pesticide loads at the catchment scale. This in turn implies using models that explicitly represent the water pathways (Aurousseau et al. 2009; Lagacherie et al. 2010; Wohlfahrt et al. 2010) as well as the mitigation measures that reduce the pesticide loads, such as vegetated strips and/or wetlands in STREAM-pesticides, SACADEAU, FLOWT and I-Phy-Bvci.

\subsection{Required data and examples of application}

The adequacy between the required data to implement a model and the data available for a particular catchment also represents an essential criterion. The more processes that are included within the model, the larger the amount of data that is needed. Table 5 synthesises the data required to implement the ten models on the respective catchments. With the exception of the SWAT and MIKE SHE ADM models, the other eight models have only been applied on the catchments shown in Table 5. This is related to the maturity of the model. The range of the studied catchments (Table 5) varies from 42 ha (Rouffach catchment, France) to $300 \mathrm{~km}^{2}$ (Leysse catchment, France). The choice of the monitored pesticides depends on the predominant agriculture that exists within the catchments (Table 3). All studied pesticides are synthetic organics and belong to three types, namely herbicides, fungicides and insecticides. The data required for the implementation of a model can be classified into three distinct types.

The first type includes the physical data used to characterize the functional units, referred to as hydrological response units (HRU) in the SWAT model or hydrological function units (HFU) in the FLOWT model (Table 3). HRUs or HFUs are subdivided parts of the catchment that account for the three-dimensional heterogeneity of the catchment and are designed to reflect different-dominant subsystems of the hydrological cycle. A digital elevation model (DEM) is required for all models to describe the topographical characteristics of the catchment, with the exception of the global approach GR5-pesticide (Table 5). The resolution of the DEM is generally a function of the catchment area in order to optimize the description of the components within the catchment, i.e. road network, hedges, ditches or grass strips and the total number of pixels.

The resolution can also be related to the mean area of the agricultural field when the model uses a mixed pixel/field discretization, such as that used for the SACADEAU model (Table 3). The number of units used for the discretizing space varies from 1 (global model, GR5-pesticides) to 107,000 (STREAM model applied to the Bourville catchment, France). The areas of these basic units vary from $25 \mathrm{~m}^{2}$ (STREAM model applied to Blosseville catchment, France) to 42 ha (GR5-pesticides applied to the Rouffach catchment, France). All of the models require some information on soil properties; what is required may vary between models (Table 5). Furthermore, land use is important due to its role in the water cycle at the atmosphere/soil interface and to localize the inputs of pesticide. Geologic or hydrogeologic data, as well as the 
permanent stream network, are only required if the processes associated to these compartments are assumed to be predominant in the study catchment (cf. Section 3.3). Components that favour or limit the hydrological connectivity, such as soil conservation practices, hedges or vegetated ditches, are necessary for SACADEAU, STREAM-pesticide and FLOWT in order to mitigate water and pesticide fluxes (Table 5). The difficulty in collecting this type of data hinders the application of such models larger than an area of about ten square kilometres even if the impact of these conservation practices and landscape components on pesticide transfer had been demonstrated (Reichenberger et al. 2007; Alletto et al. 2010; Ohliger and Schulz 2010).

The second type of data is input variables for the system. This type of data concerns the water cycle and includes the rainfall, potential evapotranspiration or variables that are needed to calculate it, such as temperature, wind speed and water vapour content of the atmosphere. The time step of the data required to characterize rainfall (Table 5) should be adapted to the hydrological dynamics of the watershed area (Table 3). The finest temporal discretization needed is 6 min (GR5-pesticides, FLOWT, PHYLOU) and can be as long as daily (MIKE SHE ADM, SACADEAU, SWAT, WESPP, I-Phy-BVci). Regardless of the catchment area, the capacity of the models to use rainfall data with high temporal resolution, i.e. few minutes, is a key point to correctly assess the impact on within-storm variability of rainfall both on pesticide persistence in soil (McGrath et al. 2008) and pesticide transfer (McGrath et al. 2009). Indeed, rainfall variability within a storm event can have a significant impact on the amount of contaminant transport especially surface applied chemicals such as pesticides, by triggering rapid flow processes as surface runoff or preferential flows (McGrath et al. 2010; Alletto et al. 2010).

Data characterizing the pesticide inputs are also needed and include the date of application, the amount, the physicochemical properties of the molecules and for some models the application mode, for example, the kind of spraying nozzles used in the I-Phy-Bvci model (Table 5). The acquisition of these data requires either an exhaustive survey from the farmers or an expert estimate, as a function of the catchment area.

The last type of data concerns the knowledge of the variables collected at the outlet of the catchment, namely the discharges, pesticide concentrations and amount of eroded soil material. For the seven hydrochemical models, these outputs are essential to select the final values of the parameters while minimizing the deviation between the observed and simulated variables, i.e. calibration of the model. The need to calibrate these models limits their use to catchments where the history of observed discharge and pesticide concentration is known. For both the VESPP and I-Phy-Bvci indicators, as well as the PHYLOU model, the availability of output variables appears less important. Indeed, this type of model generally offers a qualitative perspective of the pesticide transfer, which does not require a calibrating step of the simulated quantities as a function of the observed ones (Table 5). However, existing data at the outlet of the catchment can be used both to build indicators or multi-agent models and to validate the range of magnitude of the results. It must be noted that no model compute pesticide loads in both the dissolved and solid phases, with the exception of the SWAT model. The choice of a model thus assumes an analysis of existing and available data from the studied catchment. In this respect, how well the catchment is characterized (Table 5) depends directly on the quality of the available geographical dataset. Moreover, the available climatic data (Table 5) is directly linked to the existence and type of meteorological stations in the vicinity of the studied area. Knowledge of pesticide use and application data and measured pesticide fluxes at the outlet are most difficult information to a posteriori obtain. The rigorous application of a model (Klemes 1986) or the comparison of models (Vanclooster et al. 2000) is thus often limited by the availability of measured catchment data. Of the ten models, only two (SWAT, MIKE SHE ADM) have been applied to different catchments. The analysis of the transferability of the eight remaining models should be continued. The transferability of a model to various environmental frameworks represents an essential robustness criterion that is an important attribute for a model.

\subsection{Evaluation of models}

Model evaluation represents a key step in the development of a model. However, the notion of evaluation has different meanings according to the analysed family of models (Table 6). As discussed by Konikow and Bredehoeft (1992) and Oreskes et al. (1994), complex environmental models cannot be validated but only tested and invalidated. Therefore, the term of "evaluation" is adopted in this review instead of "validation". There are at least three types of evaluation that can then be considered (Bockstaller and Girardin 2003).

The first type relies on an a priori evaluation of the hypotheses and construction of the model by a panel of experts. This type of evaluation often represents the sole possible method of evaluation of indicators such as I-PhyBvci and VESPP. For these two indicators, the result is thus expressed in terms of qualitative scores and not quantitatively. Nevertheless, the results provided by the indicators of pesticide fate can be correlated to (a) the results of other indicators (Reus et al. 2002), (b) results of hydrochemical models such as in the case of the comparison of the VESPP model with the physically based model MIKE SHE ADM 
Table 6 Approaches of model evaluation

\begin{tabular}{|c|c|c|c|}
\hline Name & Basis for model evaluation & Output evaluation & End user evaluation \\
\hline MIKE SHE ADM & - & $\begin{array}{l}\text { Correlation coefficient and Nash criterion } \\
\text { Piezometric level (confine and non-confined } \\
\text { aquifers) } \\
\text { Flow at the outlet of the catchment }\end{array}$ & - \\
\hline LEACHM-runoff & - & $\begin{array}{l}\text { Correlation coefficient and Nash criterion } \\
\text { Flow at the outlet of the catchment } \\
\text { Visual comparison between observed/simulated } \\
\text { atrazine concentration values }\end{array}$ & - \\
\hline GR5-pesticides & - & $\begin{array}{l}\text { Nash criterion for the hydrological behaviour and } \\
\text { Theil criterion for the dynamics of pesticides } \\
\text { concentration }\end{array}$ & - \\
\hline SACADEAU & $\begin{array}{l}\text { Expert evaluation for the choice } \\
\text { of sub-models (STREAM for } \\
\text { runoff, TOPMODEL for non- } \\
\text { saturated and saturated flows) }\end{array}$ & $\begin{array}{l}\text { Correlation between observed/simulated peak of } \\
\text { pesticide concentrations, the number of peaks and } \\
\text { the cumulated concentrations }\end{array}$ & $\begin{array}{l}\text { Recommended by the chambers } \\
\text { of agriculture and the activity } \\
\text { leaders of the catchment area }\end{array}$ \\
\hline SWAT & - & Correlation coefficient and Nash criterion & - \\
\hline STREAM-pesticide & - & $\begin{array}{l}\text { Spatial evaluation of drainage network simulated/ } \\
\text { observed } \\
\text { Correlation coefficient, root mean square error: total } \\
\text { event runoff volume and pesticide concentration in } \\
\text { liquid fraction }\end{array}$ & - \\
\hline FLOWT & - & $\begin{array}{l}\text { Nash criterion for the hydrological behaviour and } \\
\text { Theil criteria for the dynamics of pesticides } \\
\text { concentration values }\end{array}$ & - \\
\hline VESPP & - & $\begin{array}{l}\text { Spearman and Kendall's rank correlation coefficient } \\
\text { Comparison with MIKE SHE ADM pesticides loads }\end{array}$ & - \\
\hline I-Phy-BVci & Expert evaluation & $\begin{array}{l}\text { Correlation coefficient between scores and pesticide } \\
\text { concentration values }\end{array}$ & $\begin{array}{l}\text { Application of I-Phy-Bvci by } \\
50 \text { vineyard farmers }\end{array}$ \\
\hline PHYLOU & - & - & $\begin{array}{l}\text { Application by the catchment's } \\
\text { stakeholders }\end{array}$ \\
\hline
\end{tabular}

(De Bruyn 2004; De Bruyn et al. 2006) and (c) the observed concentration values or fluxes, which represents the classical method of evaluation (Colin et al. 2000; Schriever et al. 2007). The environmental relevance of the obtained scores with respect to the observed pesticides flux is analysed based on rank correlation methods (Table 6), such as Spearman and Kendall (Siegel 1956).

The second type of evaluation relies on the capacity of the model to reproduce as accurately as possible the observed values in terms of water and pesticide fluxes. In this case, the environmental relevance is tested. This type of evaluation is specific to the hydrochemical models. For conceptual models, a preliminary phase of calibration is necessary owing to the inherent conceptual nature of the model parameters. Physically based models are also subjected to this step because evaluating the values of some model parameters at the scale of the computation grids is difficult and time consuming (LEACHM-runoff and MIKE SHE ADM). The evaluation first concerns the hydrological magnitudes, i.e. the discharge at the outlet, the piezometric level, and second, the pesticide concentrations and loads (Table 6). Mathematical criteria should be used to permit an objective evaluation step. The correlation coefficient or the Nash-Sutcliffe coefficient (Nash and Sutcliffe 1970) is then classically used to compare the observed and simulated hydrograms (Table 6). The Theil coefficient (Smith and Rose 1995) is also used to compare chemograms, i.e. the dynamics of observed and simulated pesticide concentrations. Furthermore, the simultaneous usage of several criteria on different outputs is recommended in order to better define the set of robust model parameters during the calibration step (Wagener et al. 2003; Joyce et al. 2010). The calibration of the GR5-pesticides and FLOWT models is carried out in two stages by (a) a calibration of the hydrological sub-model with the Nash coefficient and (b) a calibration of the chemical sub-model with the Theil coefficient (Table 6). The major restriction for model evaluation consists in the usually larger number of processes (Table 4) and needed available data for use in calibration (Table 5). Hence, only the fluxes simulated at the catchment outlet are generally compared with the observations because without data it is not possible to valid the model within the catchment, i.e. at the outlets of different sub-catchments. The imbalance between the number of 
parameters and the limited data used to calibrate the model leads to the problem of equifinality (Beven 2006).

The last type of evaluation focuses on the operational use of the models. This criterion may be predominant in multi-agent system approaches when the objective is to sensitize the interested parties to the consequences of pesticide use. The environmental relevance and the operational use have been tested by the manager of the catchment for the PHYLOU tools and by 50 winegrowers for the I-Phy-Bvci indicator (Table 6). These users are sensitized to a realistic consideration of the agricultural practices and to the clarity of the model outputs (Frewer et al. 2008). In the models whose objective is to enable a sensitization of the farmers (PHYLOU, I-PhyBvci, SACADEAU), the agricultural practices are often much more detailed than the physicochemical models.

Thus, a model should be chosen according to the type of evaluations that can be implemented. This criterion of selection cannot be dissociated from the objectives of the model, i.e. the reproduction of the observed magnitudes, the prioritization of the risky practices in terms of exposure to pesticides or sensitization and adherence of the farmers to good farming practices. Once the user has selected the model, the selection criterion of the output evaluation should be refined according to its main objective: quantitative reproduction of the concentration peak, or reproduction of the volumes and fluxes, for example.

\subsection{Sensitivity and uncertainty analyses}

Important criteria for model selection include the ability to perform a sensitivity analysis on the input parameters and to derive a measure of uncertainty from the pesticide concentration and load calculations. The analyses of sensitivity and uncertainty propagation cannot be separated from the conception and application of a model for flux of pesticide, respectively. Of the ten models discussed here (Table 5), nine have been subjected to a sensitivity analysis (Table 7), whereas only three (GR5-pesticides, FLOWT and VESPP) have an evaluation of the uncertainty propagation. Though the methods for analysing the sensitivity and the uncertainty propagation are often similar (Table 7), the objective of these two analyses differs.

The sensitivity analysis aims at identifying the key parameters of the model for which a small change has a large effect on the model results and which are therefore important to measure or estimate correctly and upon which the instrumentation effort should be focused (Kannan et al. 2007; Heuvelink et al. 2010). The study of the ten approaches shows that there is not a relationship between the model complexity and the type of sensitivity analysis that has been conducted (Table 7). The most classical procedure consists in varying the parameters around their measured or calibrated values in order to evaluate the sensitivity of the model results with respect to the values of the parameters. This procedure is used for five of the ten models (LEACHM-runoff, MIKE SHE ADM, VESPP, IPhy-Bvci and PHYLOU; Table 7). A variation of $\pm 10 \%$ of the values for each parameter is generally used (Table 7). Due to the increase of computation capacities, methods of extensive analysis of the Monte Carlo type have been brought into widespread use to perform sensitivity analysis (Verma et al. 2009). The Monte Carlo approach, used for three of the ten models (GR5-pesticides, SWAT and FLOWT), consists in extracting datasets according to the associated probability density function (Dubus and Janssen 2003). The number of combinations to be tested in order to reach an acceptable stability of the results is on the order of 1,000. The Latin Hypercube sampling method previously limits the computation time by adopting a sampling strategy to constrain the selection of a random sample (McKay et al. 1979). This technique is systematically associated to the Monte Carlo approach for the cited examples.

The analysis of the uncertainty propagation aims at studying the impact of the uncertainties associated with the outputs of the model as a function of the uncertainties affecting the parameters and the forcing variables, i.e. rainfall depth, temperature and matter inputs (Arabi et al. 2007). This type of analyses does not integrate, as source of uncertainty, the structure of the model, which necessarily simplifies the involved processes, such as the source of uncertainty (Dubus et al. 2003). The used techniques aim at associating a probability density function with each variable or parameter rather than a mean value. The construction of these probability density functions relies either on the exploitation of parameter measurements or on a priori form when such measurements are not available (Verma et al. 2009). Fuzzy logic (Zadeh 1965; Corwin and Loague 2004), Monte Carlo or affiliated techniques, such as the Bayesian approach (Beven and Binley 1992), are then used to combine the uncertainties associated to each parameter. Among the three models that were subjected to an uncertainty analysis, the fuzzy logic is used on time (VESPP), whereas the GLUE method (Beven 2002) was used for the study of uncertainty in two models (GR5-pesticides and FLOWT).

The comparison of approaches for the ten models (Table 7) underscores the possibility to proceed to a sensitivity study and to an uncertainty analysis for the four modelling approaches of pesticide fluxes. This criterion does not appear relevant to distinguish between the four types of models. Beyond the various families of models, the choice of a method to analyse the sensitivity or the uncertainty propagation is linked to (a) the input data and specifically to the availability of the probability density function for the various parameters and (b) to the 
Table 7 Parameters and methods used for sensitivity and uncertainty analysis

\begin{tabular}{|c|c|c|c|c|}
\hline Name & $\begin{array}{l}\text { Analysed parameters for } \\
\text { the sensitivity analysis }\end{array}$ & $\begin{array}{l}\text { Analysed parameters for } \\
\text { the uncertainty analysis }\end{array}$ & $\begin{array}{l}\text { Methods and values used } \\
\text { for the sensitivity analysis }\end{array}$ & $\begin{array}{l}\text { Methods and values used } \\
\text { for the uncertainty analysis }\end{array}$ \\
\hline $\begin{array}{l}\text { MIKE SHE } \\
\text { ADM (type 1) }\end{array}$ & $\begin{array}{l}\text { Percentage of karstic bypass } \\
\text { Hydraulic conductivity } \\
\text { Impervious surface coefficient } \\
\text { Rainfall data time step }\end{array}$ & - & $\begin{array}{l}\text { Different modalities } \\
{[0 \%, 25 \%, 50 \%, 95 \%]} \\
{\left[4.10^{-3}, 4.10^{-4}, 4.10^{-5}\right] \mathrm{m} \mathrm{s}^{-1}} \\
\text { Percentage of impervious } \\
\text { Daily and hourly time step }\end{array}$ & - \\
\hline $\begin{array}{l}\text { LEACHM-runoff } \\
\text { (type 1) }\end{array}$ & $\begin{array}{l}\text { Van Genuchten parameters } \\
\text { (moisture retention curve) } \\
\text { Hydraulic conductivity } \\
\text { (unsaturated flow) }\end{array}$ & - & $\begin{array}{l}\text { Different modalities } \\
\qquad \begin{array}{l}K_{\mathrm{s}}-10 \% ; K_{\mathrm{s}} ; K_{\mathrm{s}}+5 \% ; K_{\mathrm{s}}+ \\
10 \% ; K_{\mathrm{s}}+20 \% ; K_{\mathrm{s}}+30 \%\end{array}\end{array}$ & - \\
\hline $\begin{array}{l}\text { GR5-pesticides } \\
\text { (type 2) }\end{array}$ & $\begin{array}{l}\text { All parameters ( } 7 \text { for the } \\
\text { hydrological sub-model } \\
\text { and } 6 \text { for the chemical } \\
\text { sub-model) }\end{array}$ & $\begin{array}{l}\text { All parameters ( } 7 \text { for the } \\
\text { hydrological sub-model } \\
\text { and } 6 \text { for the chemical } \\
\text { sub-model) }\end{array}$ & $\begin{array}{l}\text { Monte Carlo analysis with } \\
\text { Latin hypercube sampling }\end{array}$ & $\begin{array}{l}\text { Adaptation of the GLUE } \\
\text { method (Bayesian approach) }\end{array}$ \\
\hline $\begin{array}{l}\text { SACADEAU } \\
\text { (type 2) }\end{array}$ & - & - & - & - \\
\hline SWAT (type 2) & $\begin{array}{l}12 \text { hydrological parameters } \\
\text { and } 12 \text { parameters for the } \\
\text { fate of pesticide }\end{array}$ & - & $\begin{array}{l}\text { Monte Carlo analysis with } \\
\text { Latin hypercube sampling }\end{array}$ & - \\
\hline $\begin{array}{l}\text { STREAM-pesticide } \\
\text { (type 2) }\end{array}$ & - & 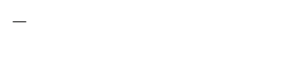 & 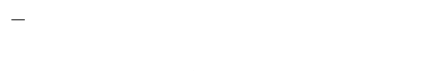 & 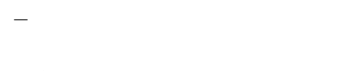 \\
\hline FLOWT (type 2) & $\begin{array}{l}\text { All parameters ( } 6 \text { for the } \\
\text { hydrological sub-model } \\
\text { and } 1 \text { for the chemical } \\
\text { sub-model) }\end{array}$ & $\begin{array}{l}\text { All parameters ( } 6 \text { for the } \\
\text { hydrological sub-model } \\
\text { and } 1 \text { for the chemical } \\
\text { sub-model) }\end{array}$ & $\begin{array}{l}\text { Monte Carlo analysis with } \\
\text { Latin hypercube sampling }\end{array}$ & $\begin{array}{l}\text { Adaptation of the GLUE methoc } \\
\text { (Bayesian approach) }\end{array}$ \\
\hline \multirow[t]{3}{*}{ VESPP (type 3) } & $\begin{array}{l}\text { Half time life of pesticide } \\
\text { Slope }\end{array}$ & Leaf Area Index & $\begin{array}{l}\text { Variation of } 10 \% \text { of the mean } \\
\text { value of the parameters }\end{array}$ & $\begin{array}{l}\text { Fuzzy sets and Monte Carlo } \\
\text { analysis }\end{array}$ \\
\hline & Proximity of river network & Half time life of pesticide & & \\
\hline & $\begin{array}{l}\text { Effective rainfall } \\
K_{\mathrm{oc}}\end{array}$ & $\begin{array}{l}K_{\mathrm{oc}} \\
f_{\mathrm{oc}}\end{array}$ & & $\begin{array}{l}\text { Triangular function } \\
\text { [min; mean; max }]\end{array}$ \\
\hline $\begin{array}{l}\text { I-Phy-Bvci } \\
\text { (type 3) }\end{array}$ & Undefined & - & $\begin{array}{l}3 \text { parameters (mitigation efficiency } \\
\text { of grass strips, pesticide retention } \\
\text { of plot, type of runoff pathway) }\end{array}$ & - \\
\hline $\begin{array}{r}\text { PHYLOU } \\
\text { (type 4) }\end{array}$ & $\begin{array}{l}\text { Pesticide input period } \\
\text { Pesticide amount } \\
\text { Landscape mosaic }\end{array}$ & - & $\begin{array}{l}\text { Probabilistic behaviour of farmers } \\
\text { with respect to agricultural } \\
\text { practices (uniform, normal, bimodal) }\end{array}$ & - \\
\hline
\end{tabular}

$K_{o c}$ organic carbon partition coefficient (cubic centimetres per gram), $f_{o c}$ soil organic carbon fraction, $K_{S}$ saturated hydraulic conductivity, GLUE generalized likelihood uncertainty estimation

computation time, in particular for the Monte Carlo approaches in the case of the models that include a large number of parameters. The sensitivity and uncertainty analyses are essential steps to correctly interpret the model results (Trevisan and Vischetti 2004; Zheng and Keller 2006; Brown 2010), and the ability to perform these analyses should be considered when selecting an appropriate model.

\section{Conclusion}

The review article outlines the nine main following points.

1. In terms of the number of studies identified between 1975 and 2010, indicators and conceptual models are the most popular approaches to assess the transfer of pesticides to surface water at the catchment scale
(Fig. 1), accounting for $59 \%$ and $33 \%$ of the studies, respectively, due to a trade-off between environmental relevance and adaptation to user's needs.

2. The latest indicators developed are inferred from the results of proven conceptual or physically based leaching and hydrological models to combine the strengths of each approach. These results are combined into a synthetic indicator according soil types, soil management, pesticides and climatic scenario database. Therefore, development of this type of indicator requires large numbers of simulations but the synthetic indicator can be useful in the decision-making process.

3. Only a handful of physically based models have addressed both flow and pesticide transport at the catchment scale as affected by the internal heterogeneity of the system largely due to the significant data required to operate them. However, it is only physically based models that can simulate the impact of changes 
to the catchment alterations in land use and practice as well as the concerns arising from global change. Physically based models integrate feedbacks between hydrological and chemical processes not possible from empirical studies alone. More knowledge of mitigation measures is needed to correctly describe and integrate these landscape components into physically based models to assess the sustainability of farming activities regarding pesticide use.

4. Depending on the family of pesticides, the ability of models to assess the pesticide loads both in the dissolved and particulate phases is a key issue not properly addressed by many indices or models. A key way forward is the integration of erosion processes with the fate of pesticide adsorbed to these particles.

5. At the scale of the catchment, hydrological connectivity, i.e. the connection between the fields and the hydrologic network or groundwater, is perhaps the primary hydrological variable required to correctly assess rapid flow processes as surface runoff or preferential flows and associated pesticide transfer. This in turn implies using models that explicitly represent the connectedness of surface and/or subsurface water pathways including mitigation measures and those that use rainfall data with high temporal resolution to correctly assess the impact on withinstorm variability of rainfall both on pesticide persistence in soil and pesticide transfer.

6. The level of complexity of the model should be adapted to the study objectives and to the users. When the involvement of the farming profession is a priority, a high complexity may result in a rejection of some interested parties that do not possess the necessary scientific background. Conversely, qualitative models, such as specific indicators or multi-agent systems may not produce conclusive quantitative results, such as when and under what circumstances drinking water limits will be exceeded.

7. The underlying structure, assumptions, hypotheses and why a model was developed should correspond to the specificities of the studied catchments. While the use of a model beyond its intended use may provide fair results for a particular variable, such as the runoff volume, it may give an erroneous representation of the pathways of water transfer. A systematic and detailed investigation of the model hypotheses, as well as the modelled processes and the environmental compartments, is strongly advised prior to selection.

8. The type of expected evaluation, i.e. the reproduction of the observed magnitudes, the organization into a hierarchy of the agricultural practices with respect to the exposure of pesticides or the sensitization and adhesion of the agricultural profession to good agricul- tural practices, should directly determine the choice of a modelling approach.

9. Evaluating the sensitivity of the model and the uncertainty associated with the results should necessarily be integrated in the modelling process in order to appropriately interpret the results.

Acknowledgements The paper benefited much from discussions with R. Coupe from USGS and G. Imfeld from LHyGeS.

\section{References}

Alletto L, Coquet Y, Benoit P, Heddadj J, Barriuso E (2010) Tillage management effects on pesticide fate in soils. A review. Agron Sustain Dev 30:367-400. doi:10.1051/agro/2009018

Alvarez-Benedi J, Munoz-Carpena R, Vanclooster M (2004) Modeling as a tool for the characterization of soil water and chemical fate and transport. In: Alvarez-Benedi J (ed) Soil water solute process characterization: an integrated approach. CRC, Hoboken, pp 87117

Ambroise B (2004) Variable "active" versus "contributing" areas or periods: a necessary distinction. HP-Today Invited Commentary. Hydrol Process 18(6):1149-1155. doi:10.1002/hyp.5536

Andreu V, Picó Y (2004) Determination of pesticides and their degradation products in soil: critical review and comparison of methods. TrAC Trends Anal Chem 23(10-11):772-789. doi:10.1016/j.trac.2004.07.008

Arabi M, Govindaraju RS, Hantush MMA (2007) Probabilistic approach for analysis of uncertainty in the evaluation of watershed management practices. J Hydrol 333(2-4):459-471. doi:10.1016/j.jhydrol.2006.09.012

Arias-Estevez M, Lopez-Periago E, Martinez-Carballo E, SimalGandara J, Mejuto JC, Garcia-Rio L (2008) The mobility and degradation of pesticides in soils and the pollution of groundwater resources. Agr Ecosyst Environ 123(4):247-260. doi:10.1016/ j.agee.2007.07.011

Aurousseau P, Gascuel-Odoux C, Squividant H, Trepos R, Tortrat F, Cordier MO (2009) A plot drainage network as a conceptual tool for the spatial representation of surface flow pathways in agricultural catchments. Comput geosci 35:276-288. doi:10.1016/ j.cageo.2008.09.003

Balderacchi M, Di Guardo A, Vischetti C, Trevisan M (2008) The effect of crop rotation on pesticide leaching in a regional pesticide risk assessment. Environ Sci Technol 42:8000-8006. doi:10.1021/es $801287 \mathrm{w}$

Barreteau O, Cernesson F (2003) Orb case study (Phylou model) in report of workpackage 5 of the Firma European Project. In: Warwick C (ed). University of Oxford, England, pp 55-59

Bedos C, Rousseau-Djabri MF, Gabrielle B, Flura D, Durand B, Barriuso E, Cellier P (2006) Measurement of trifluralin volatilization in the field: relation to soil residue and effect of soil incorporation. Environ Pollut 144(3):958-966. doi:10.1016/j. envpol.2006.01.043

Bedos C, Rousseau-Djabri MF, Flura D, Masson S, Barriuso E, Cellier P (2002) Rate of pesticide volatilization from soil: an experimental approach with a wind tunnel system applied to trifluralin. Atmos Environ 36(39-40):5917-5925. doi:10.1016/S1352-2310 (02)00775-6

Beven KJ, Binley A (1992) The future of distributed models: model calibration and uncertainty prediction. Hydrol Process 6(3):279298. doi:10.1002/hyp.3360060305 
Beven KJ (2002) Towards an alternative blueprint for a physically based digitally simulated hydrologic response modelling system. Hydrol Process 16(2):189-206. doi:10.1002/hyp.343

Beven KJ (2006) A manifesto for the equifinality thesis. J Hydrol 320 (1-2):18-36. doi:10.1016/j.jhydrol.2005.07.007

Blanchoud H, Moreau-Guigon E, Farrugia F, Chevreuil M, Mouchel JM (2007) Contribution by urban and agricultural pesticide uses to water contamination at the scale of the Marne watershed. Sci Total Environ 375(1-3):168-179. doi:10.1016/j.scitotenv.2006.12.009

Bloomfield JP, Williams RJ, Gooddy DC, Cape JN, Guha P (2006) Impacts of climate change on the fate and behaviour of pesticides in surface and groundwater-a UK perspective. Sci Total Environ 369(1-3):163-177. doi:10.1016/j.scitotenv.2006.05.019

Bockstaller C, Girardin P (2003) How to validate environmental indicators? Agr Syst 76(2):639-653. doi:10.1016/S0308-521X (02)00053-7

Borah D, Bera M (2004). Watershed-scale hydrologic and nonpointsource pollution models: Review of applications. Trans ASAE 47(3): 789-804.

Borggaard OK, Gimsing AL (2008) Fate of glyphosate in soil and the possibility of leaching to ground and surface waters: a review. Pest Manag Sci 64(4):441-456. doi:10.1002/ps.1512

Bousquet F, Le Page C (2004) Multi-agent simulations and ecosystem management: a review. Ecol Model 176(3-4):313-332. doi:10.1016/j.ecolmodel.2004.01.011

Brady JA, Wallender WW, Werner I, Mostafazadeh FB, Zalom FG, Oliver MN, Wilson BW, Mata MM, Henderson JD, Deanovic LA, Upadhaya S (2006) Pesticide runoff from orchard floors in Davis, California, USA: a comparative analysis of diazinon and esfenvalerate. Agr Ecosyst Environ 115(1-4):56-68. doi:10.1016/j. agee.2005.12.009

Brown JD (2010) Prospects for the open treatment of uncertainty in environmental research. Prog Phys Geogr 34(1):75-100. doi: $10.1177 / 0309133309357000$

Campbell CG, Garrido F (2004) Spatial and temporal variability of soil processes: implication for method selection and characterization studies. In: Alvarez-Benedi J (ed) Soil water solute process characterization: an integrated approach. CRC, Hoboken, pp 59-80

Colin F, Puech C, de Marsily G (2000) Relations between triazine flux, catchment topography and distance between maize fields and the drainage network. J Hydrol 236:139-152. doi:10.1016/ S0022-1694(00)00288-2

Corwin DL, Loague K (2004) Multidisciplinarity approach for assessing subsurface non-point source pollution. In: AlvarezBenedi J (ed) Soil water solute process characterization: an integrated approach. CRC, Hoboken, pp 1-46

Christiansen JS, Thorsen M, Clausen T, Hansen S, Refsgaard JC (2004) Modelling of macropore flow and transport processes at catchment scale. J Hydrol 299:136-158. doi:10.1016/j.jhy drol.2003.10.018

De Bruyn B (2004) Study of water vulnerability to phytosanitary products: environmental indicator and mechanistic model, with a view of improving the management of the Leysse catchment area (Savoie, France). Ph.D. report, LTHE, Université Joseph Fourier, Grenoble, France (in French)

De Bruyn B, Freissinet C, Vauclin M (2006) An indice for pesticide vulnerability of surface waters: assessment on the Leysse catchment (Savoie). Houille Blanche-Revue Internationale de l'Eau 2:106-112. doi:10.1051/lhb:200602014

Delphin JE, Chapot JY (2006) Leaching of atrazine, metolachlor and diuron in the field in relation to their injection depth into a silt loam soil. Chemosphere 64(11):1862-1869. doi:10.1016/j.chemosphere.2006.01.049

Devillers J, Farret R, Girardin P, Rivière JL, Soulas G (2005) Indicateurs pour évaluer les risques liés à l'utilisation des pesticides. TEC\&DOC, Paris
Dordio AV, Teimão J, Ramalho I, Carvalho AJP, Estêvão Candeias AJ (2007) Selection of a support matrix for the removal of some phenoxyacetic compounds in constructed wetlands systems. Sci Total Environ 380(1-3):237-246. doi:10.1016/j.scitotenv.2007.02.015

Dubus IG, Brown CD, Beulke S (2003) Sources of uncertainty in pesticide fate modelling. Sci Total Environ 317(1-3):53-72. doi:10.1016/S0048-9697(03)00362-0

Dubus IG, Janssen PHM (2003) Issues of replicability in Monte Carlo modeling: a case study with a pesticide leaching model. Environ Toxicol Chem 22(12):3081-3087. doi:10.1897/ $02-470$

Dubus IG, Surdyk N (2006) State-of-the-art review on pesticide fate models and environmental indicators. Report DL\#4 of the FP6 EU-funded FOOTPRINT project: 39 p. Available from www. eu-footprint.org

Dubus IG, Azimonti G, Bach M, Barriuso E, Bidoglio G, Bouraoui F, Fialkiewicz W, Fowler HJ, Francois O, Hojberg A, Hollis JM, Jarvis NJ, Kajewski I, Kjaer J, Lewis K, Lobnik F, Lolos P, Nolan BT, Real B, Reichenberger S, Stenemo F, Suhadolc M, Surdyk N, Vavoulidou-Theodorou E (2007) Developing tools for pesticide risk assessment and management at three different scales in Europe: the FOOTPRINT project. In: Del Re AAM, Carpi E, Fragoulis G, Trevisan M (eds) Symposium pesticide chemistry-environment fate and ecological effects, XIIIth edn. La Goliardica Pavese, Piacenza, pp 966-973

Du Preez LH, van Rensburg PJJ, Jooste AM, Carr JA, Giesy JP, Gross TS, Kendall RJ, Smith EE, Van Der Kraak G, Solomon KR (2005) Seasonal exposures to triazine and other pesticides in surface waters in the western Highveld corn-production region in South Africa. Environ Pollut 135(1):131-141. doi:10.1016/j. envpol.2004.09.019

Durand P, Gascuel-Odoux C, Cordier MO (2002) Parameterisation of hydrological models: a review and lessons learned from studies of an agricultural catchment (Naizin, France). Agronomie 22 (2):217-228. doi:10.1051/agro:2002001

Faria MS, Nogueira AJA, Soares AMVM (2007) The use of Chironomus riparius larvae to assess effects of pesticides from rice fields in adjacent freshwater ecosystems. Ecotoxicol Environ Saf 67(2):218-226. doi:10.1016/j.ecoenv.2006.11.018

Fiener P, Auerswald K, Weigand S (2005) Managing erosion and water quality in agricultural watersheds by small detention ponds. Agr Ecosyst Environ 110(3-4):132-142. doi:10.1016/j.agee.2005.03.012

Finizio A, Villa S (2002) Environmental risk assessment for pesticides: a tool for decision making. Environ Impact Asses 22 (3):235-248. doi:10.1016/S0195-9255(02)00002-1

Frewer L, Fischer A, van den Brink P, Brock TCM, Brown CD, Byrne P, Crocker J, Görlitz G, Hart A, Scholderer J, Solomon K (2008) Optimising the communication of probabilistic risk assessments to end-users and decisions-makers. Hum Ecol Risk Assess 14:166-178. doi:10.1080/10807030701790355

Frey MP, Schneider MK, Dietzel A, Reichert P, Stamm C (2009) Predicting critical source areas for diffuse herbicide losses to surface waters: role of connectivity and boundary conditions. J Hydrol 365(1-2):23-36. doi:10.1016/j.jhydrol.2008.11.015

Gascuel-Odoux C, Aurousseau P, Cordier MO, Durand P, Garcia F, Masson V, Salmon-Monviola J, Tortrat F, Trepos R (2009) A decision-oriented model to evaluate the effect of land use and agricultural management on herbicide contamination in stream water. Environ Model Softw 24:1433-1446. doi:10.1016/j.env soft.2009.06.002

Gavrilescu M (2005) Review: fate of pesticides in the environment and its bioremediation. Eng Life Sci 5(6):497-526. doi:10.1002/ elsc. 200520098

Gil Y, Sinfort C (2005) Emission of pesticides to the air during sprayer application: a bibliographic review. Atmos Environ 39(28):51835193. doi:10.1016/j.atmosenv.2005.05.019 
Gooddy DC, Chilton PJ, Harrison I (2002) A field study to assess the degradation and transport of diuron and its metabolites in a calcareous soil. Sci Total Environ 297(1-3):67-83. doi:10.1016/ S0048-9697(02)00079-7

Gras R, Benoit M, Deffontaines JP, Duru M, Lafarge M, Langlet A, Osty PL (1989) Le fait technique en agronomie. Activité agricole, concepts et méthodes d'étude. Institut National de la Recherche Agronomique, L'Harmattan, Paris

Gregoire C (2006) Non-point source pollution in small vineyard catchments: characterisation and modelling of transfer processes. Authorization to manage research report (HDR in French). Ecole Nationale du Génie de l'Eau et de l'Environnement de Strasbourg, Université Louis Pasteur, Strasbourg

Gregoire C, Elsaesser D, Huguenot D, Lange J, Lebeau T, Merli A, Mose R, Passeport E, Payraudeau S, Schütz T, Schulz R, TapiaPadilla G, Tournebize J, Trevisan M, Wanko A (2009) Mitigation of agricultural nonpoint-source pesticide pollution in artificial wetland ecosystems: an interdisciplinary approach in the EU ArtWET project. Environmental Chem Lett 7(3):205-231. doi:10.1007/s10311-008-0167-9

Gregoire C, Payraudeau S, Domange N (2010) Use and fate of 17 pesticides at the catchment scale. Int J Environ Anal Chem 90(36):406-420. doi:10.1080/03067310903131230

Halberg N, Verschuur G, Goodlass G (2005) Farm level environmental indicators; are they useful?: an overview of green accounting systems for European farms. Agr Ecosyst Environ 105(1-2):195212. doi:10.1016/j.agee.2004.04.003

Hamilton SF, Sunding DL, Zilberman D (2003) Public goods and the value of product quality regulations: the case of food safety. J Public Econ 87 (3-4):799-817. doi:10.1016/S0047-2727(01)00103-7

Henriksen HJ, Rasmussen P, Brandt G, von Bülow D, Jensen FV (2007) Public participation modelling using Bayesian networks in management of groundwater contamination. Environ Modell Softw 22(8):1101-1113. doi:10.1016/j.envsoft.2006.01.008

Heuvelink GBM, Burgers SLGE, Tiktak A, Van Den Berg F (2010) Uncertainty and stochastic sensitivity analysis of the GeoPEARL pesticide leaching model. Geoderma 155(3-4):186-192. doi:10.1016/j.geoderma.2009.07.004

Holvoet K, Seuntjens P, Vanrolleghem P (2007) Monitoring and modeling pesticide fate in surface waters at the catchment scale. Ecol Model 209(1):53-64. doi:10.1016/j.ecolmodel.2007.07.030

Holvoet K, van Griensven A, Gevaert V, Seuntjens P, Vanrolleghem PA (2008) Modifications to the SWAT code for modelling direct esticide losses. Environ Modell Softw 23(1):72-81. doi:10.1016/j.envsoft.2007.05.002

Holvoet K, van Griensven A, Seuntjens P, Vanrolleghem PA (2005) Sensitivity analysis for hydrology and pesticide supply towards the river in SWAT. Phys Chem Earth 30(8-10):518-526. doi:10.1016/j.pce.2005.07.006

Houdart M (2005) Spatial organisation of agricultural activities and water pollution by pesticides Modelling in Capot's watershed, Martinique (French West Indies). Ph.D. Université des Antilles et de la Guyane, Fort de France, Martinique, France (in French). Available from http://cormas.cirad.fr/pdf/theseHoudart.pdf

Houdart M, Tixier P, Lassoudière SF (2009) Assessing pesticide pollution risk: from field to watershed. Agron Sustain Dev 29:321-327. doi:10.1051/agro:2008042

IISD (1997) Assessing sustainable development. International Institute for Sustainable Development, Winnipeg

Jantunen APK, Trevisan M, Capri E (2004) Computer models for characterizing the fate of chemicals in soil: pesticide leaching models and their practical applications. In: Alvarez-Benedi J (ed) Soil water solute process characterization: an integrated approach. CRC, Hoboken, pp 715-751

Jetten V, Govers G, Hessel R (2003) Erosion models: quality of spatial predictions. Hydrol Process 17(5):887-900. doi:10.1002/hyp. 1168
Joannon A, Papy F, Martin P, Souchère V (2005) Planning work constraints within farms to reduce runoff at catchment level. Agr Ecosyst Environ 111(1-4):13-20. doi:10.1016/j.agee.2005.04.021

Joyce BA, Wallender WW, Mailapalli DR (2010) Application of pesticide transport model for simulating diazinon runoff in California's central valley. J Hydrol 395(1-2):79-90. doi:10.1016/ j.jhydrol.2010.10.017

Kannan N, White SM, Worrall F, Whelan MJ (2007) Sensitivity analysis and identification of the best evapotranspiration and runoff options for hydrological modelling in SWAT-2000. J Hydrol 332(3-4):456-466. doi:10.1016/j.jhydrol.2006.08.001

Klemes V (1986) Dilettantism in hydrology: transition or destiny? Water Resour Res 22(9):177-188. doi:10.1029/WR022i09Sp0177S

Köhne JM, Köhne S, Simunek J (2009) A review of model applications for structured soils: b) pesticides transport. J Contam Hydrol 104:36-60. doi:10.1016/j.jconhyd.2008.10.003

Kolditz O, Du Y, Bürger C, Delfs J, Kuntz D, Beinhorn M, Hess M, Wang W, van der Grift B, te Stroet C (2007) Development of a regional hydrologic soil model and application to the BeerzeReusel drainage basin. Environ Pollut 148(3):855-866. doi:10.1016/j.envpol.2007.01.046

Konikow LF, Bredehoeft JD (1992) Ground-water models cannot be validated. Adv Water Resour 15:75-83. doi:10.1016/0309-1708 (92) $90033-X$

Konstantinou IK, Hela DG, Albanis TA (2006) The status of pesticide pollution in surface waters (rivers and lakes) of Greece. Part I. Review on occurrence and levels. Environ Pollut 141(3):555570. doi:10.1016/j.envpol.2005.07.024

Lagacherie P, Rabotin M, Colin F, Moussa R, Voltz M (2010) GeoMHYDAS: a landscape discretization tool for distributed hydrological modeling of cultivated areas. Comput Geol 36 (8):1021-1032. doi:10.1016/j.cageo.2009.12.005

Lecomte V (1999) Movement of agricultural chemicals through runoff and erosion from the cultivated plot to the catchment. Ph.D. ENGREF, Paris, France (in French)

Lehmann P, McGrath G, Tromp-van Meerveld HJ, McDonnell JJ (2007) Rainfall threshold for hillslope outflow: an emergent property of flow pathway connectivity. Hydrol Earth Syst Sci 11:1047-1063. doi:10.5194/hess-11-1047-2007

Leu C, Singer H, Stamm C, Müller SR, Schwarzenbach RP (2004a) Simultaneous assessment of sources, processes and factors influencing herbicide losses to surface waters in a small agricultural catchment. Environ Sci Technol 38(14):3827-3834. doi:10.1021/es0499602

Leu C, Singer H, Stamm C, Müller SR, Schwarzenbach RP (2004b) Variability of herbicide losses from 13 fields to surface water within a small catchment after a controlled herbicide application. Environ Sci Technol 38(14):3835-3841. doi:10.1021/es0499593

Louchart X, Voltz M, Andrieux P, Moussa R (2001) Herbicides runoff at field and watershed scales in a Mediterranean vineyard area. J Environ Qual 30(3):982-991. doi:10.2134/jeq2001.303982x

Luo YZ, Zhang MH (2009) A geo-referenced modeling environment for ecosystem risk assessment: organophosphate pesticides in an agriculturally dominated watershed. J Environ Qual 38(2):664 674. doi: $10.2134 /$ jeq2008.0216

Madier S (2007) From the measurement to the modelling of transfers of pesticides on the catchment scale: quantification of the uncertainties and definition of sampling strategies. Ph.D. Agro Paris tech, Paris, France (in French). Available from http://www-engees.u-strasbg.fr/ fileadmin/user_upload/pdf/cevh/Madier_THESE.pdf

Maison P (2000) A hydrological model of non-point pollution behaviour in watershed-simplified mechanistic approach of the non saturated zone. Ph.D. report of Institut national polytechnic de Toulouse, Toulouse, France (in French). Available from http:// www.infotheque.info/ressource/6039.html 
McGrath GS, Hinz C, Sivapalan M (2008) Modeling the effect of rainfall intermittency on the variability of solute persistence at the soil surface. Water Resour Res 44(9):W09432. doi:0.1029/ 2007WR006652

McGrath GS, Hinz C, Sivapalan M (2009) A preferential flow leaching index. Water Resour Res 45:W11405. doi:10.1029/2008WR007265

McGrath GS, Hinz C, Sivapalan M, Dressel J, Putz T, Vereecken H (2010) Identifying a rainfall event threshold triggering herbicide leaching by preferential flow. Water Resour Res 46:W02513. doi:10.1029/2008WR007506

McKay MD, Conover WJ, Beckman RJ (1979) A comparison of three methods for selecting values of input variables in the analysis of output from computer code. Technometrics 21:239-245. doi: $10.2307 / 1268522$

Mitchell G, May A, McDonald A (1995) PICABEU: a methodological framework for the development of indicators of sustainable development. Int J Sustain Dev World Ecol 2:104-123. doi:10.1080/13504509509469893

Mitsch WJ, Gosselink JG (2007) Wetlands. Wiley, New York

Moore MT, Rodgers JH, Smith S, Cooper CM (2001) Mitigation of metolachlor-associated agricultural runoff using constructed wetlands in Mississippi, USA. Agr Ecosyst Environ 84(2):169-176. doi:10.1016/S0167-8809(00)00205-X

Moore MT, Bennett ER, Cooper CM, Smith S, Farris JL, Drouillard $\mathrm{KG}$, Schulz R (2006) Influence of vegetation in mitigation of methyl parathion runoff. Environ Pollut 142(2):288-294. doi:10.1016/j.envpol.2005.10.009

Moreby SJ, Southway SE (1999) Influence of autumn applied herbicides on summer and autumn food available to birds in winter wheat fields in southern England. Agr Ecosyst Environ 72 (3):285-297. doi:10.1016/S0167-8809(99)00007-9

Mouvet C, Albrechtsen HJ, Baran N, Chen T, Clausen L, Darsy C, Desbionne S, Douguet J-M, Dubus IG, Esposito A, Fialkiewicz W, Gutierrez A, Haverkamp R, Herbst M, Howles D, Jarvis NJ, Jørgensen PR, Larsbo M, Meiwirth K, Mermoud A, Morvan X, Normand B, O'Connor M, Ritsema C, Roessle S, Roulier S, Soutter M, Stenemo F, Thiéry D, Trevisan M, Vachaud G, Vereecken H, Vischetti C (2004) PEGASE. Pesticides in European Groundwaters: detailed study of representative aquifers and simulation of possible evolution scenarios. In: Dubus IG, Mouvet C (eds) Final report of the European project \#EVK1CT1990-00028. BRGM/RP-52897-FR, 358 p. doi:10.1016/j. agee.2006.08.016

Müller K, Magesan GN, Bolan NS (2007) A critical review of the influence of effluent irrigation on the fate of pesticides in soil. Agr Ecosyst Environ 120(2-4):93-116

Nash JE, Sutcliffe JV (1970) River flow forecasting through conceptual models, part I: a discussion of principles. J Hydrol 10(3):282-290. doi:10.1016/0022-1694(70)90255-6

Ocampo CJ, Sivapalan M, Oldham C (2006) Hydrological connectivity of upland-riparian zones in agricultural catchments: implications for runoff generation and nitrate transport. J Hydrol 331(3-4):643-658. doi:10.1016/j.jhydrol.2006.06.010

Ohliger R, Schulz R (2010) Water body and riparian buffer strip characteristics in a vineyard area to support aquatic pesticide exposure assessment. Sci Total Environ 408(22):5405-5413. doi: $10.1016 /$ j.scitotenv.2010.08.025

Oreskes N, Shrader-Frechette K, Belitz K (1994) Verification, validation and confirmation of numerical models in the Earth sciences. Sciences 263:641-646. doi:10.1126/science.263.5147.641

Pavlis M, Cummins E, McDonnell K (2010) Groundwater vulnerability assessment of plant protection products: a review. Hum Ecol Risk Assess 16(3):621-650. doi:10.1080/10807031003788881

Payraudeau S, van der Werf HMG (2005) Environmental impact assessment for a farming region: a review of methods. Agr Ecosyst Environ 107:1-19. doi:10.1016/j.agee.2004.12.012
Pell M, Stenström J (2004) Evaluation and characterization of soil microbiological Processes. In: Alvarez-Benedi J (ed) Soil water solute process characterization: an integrated approach. CRC, Hoboken, pp 559-580

Pesce S, Martin-Laurent F, Rouard N, Robin A, Montuelle B (2010) Evidence for adaptation of riverine sediment microbial communities to diuron mineralization: incidence of runoff and soil erosion. J Soils Sediments 10(4):698-707. doi:10.1007/s11368010-0202-x

Poissant L, Beauvais C, Lafrance P, Deblois C (2008) Pesticides in fluvial wetlands catchments under intensive agricultural activities. Sci Total Environ 404(1):182-195. doi:10.1016/j.scitotenv.2008.05.030

Pot V, Šimůnek J, Benoit P, Coquet Y, Yra A, Martínez-Cordón MJ (2005) Impact of rainfall intensity on the transport of two herbicides in undisturbed grassed filter strip soil cores. J Contam Hydrol 81(1-4):63-88. doi:10.1016/j.jconhyd.2005.06.013

Quilbe R, Rousseau AN, Lafrance P, Leclerc J, Amrani M (2006) Selecting a pesticide fate model at the watershed scale using a multi-criteria analysis. Water Qual Res J Can 41(3):283-295

Ramwell CT, Heather AIJ, Shepherd AJ (2002) Herbicide loss following application to a roadside. Pest Manag Sci 58:695701. doi: $10.1002 /$ ps.506

Reichenberger S, Bach M, Skitschak A, Frede HG (2007) Mitigation strategies to reduce pesticide inputs into ground- and surface water and their effectiveness; a review. Sci Total Environ 384:135. doi:10.1016/j.scitotenv.2007.04.046

Reus J, Leendertse P, Bockstaller C, Fomsgaard I, Gutsche V, Lewis K, Nilsson C, Pussemier L, Trevisan M, van der Werf H (2002) Comparison and evaluation of eight pesticide environmental risk indicators developed in Europe and recommendations for future use. Agr Ecosyst Environ 90(2):177-187. doi:10.1016/S01678809(01)00197-9

Rose MT, Sanchez-Bayo F, Crossan AN, Kennedy LR (2006) Pesticide removal from cotton farm tailwater by a pilot-scale ponded wetland. Chemosphere 63:1849-1858. doi:10.1016/j. chemosphere.2005.10.024

Schriever CA, von der Ohe PC, Liess M (2007) Estimating pesticide runoff in small streams. Chemosphere 68(11):2161-2171. doi:10.1016/j.chemosphere.2007.01.086

Siegel S (1956) Nonparametric statistics for the behavioural sciences. McGraw-Hill, New York

Siimes K, Kämäri J (2003) A review of available pesticide leaching models: selection of models for simulation of herbicide fate in Finnish sugar beet cultivation. Boreal Environ Res 8:31-51

Smith EP, Rose KA (1995) Model goodness-of-fit analysis using regression and related techniques. Ecol Model 77:49-64. doi:10.1016/0304-3800(93)E0074-D

Sood C, Bhagat RM (2005) Interfacing geographical information systems and pesticide models. Curr Sci 89(8):1362-1370

Stenrød M, Heggen HE, Bolli RI, Eklo OM (2008) Testing and comparison of three pesticide risk indicator models under Norwegian conditions - a case study in the Skuterud and Heiabekken catchments. Agr Ecosyst Environ 123(1-3):15-19. doi:10.1016/j.agee.2007.03.003

Takken I, Govers G, Jetten V, Nachtergaele J, Steegen A, Poesen J (2005) The Influence of both descriptions and runoff patterns on predictions from a spatially distributed soil erosion model. Earth surf Process Landf 30(2):213-229. doi:10.1002/esp.1176

Therrien R, McLaren RG, Sudicky EA, Panday SM (2005) HydroGeoSphere: a three-dimensional numerical model describing fully-integrated subsurface and surface flow and solute transport. Technical report. Groundwater Simulations Group, Waterloo

Thiollet-Scholtus M (2004) Construction d'un indicateur de qualité des eaux de surface vis-à-vis des produits phytosanitaires à l'échelle $\mathrm{du}$ bassin versant viticole. Thèse Institut national Polytechnique de Lorraine, Colmar, France, (in French). + annexes. Available 
from http://www.inra.fr/theses/these-integrale/Theses/thiollet/pdf/ these.pdf

Tiktak A, Boesten JJTI, van der Linden AMA, Vanclooster M (2006) Mapping ground water vulnerability to pesticide leaching with a process-based metamodel of EuroPEARL. J Environ Qual 35:1213-1226. doi:10.2134/jeq2005.0377

Tortrat F (2005) Decision oriented modelling of herbicide transfer by surface and subsurface flow in agricultural catchments. Ph.D. Rennes ENSA, INRA-Agrocampus, Rennes, France (in French). Available from http://www.rennes.inra.fr/umrsas/documentation/ publications_de 1 unite/theses

Trevisan M, Vischetti C (2004) Assessment of uncertainty associated with the extent of simulation processes from point to catchment: application to $1 \mathrm{D}$ pesticide leaching models. In: Alvarez-Benedi J (ed) Soil water solute process characterization: an integrated approach. CRC, Hoboken, pp 673-690, ISBN: 978140032086

Vanclooster M, Boesten JJTI, Trevisan M, Brown CD, Capri E, Eklo OM, Gottesbüren B, Gouy V, van der Linden AMA (2000) A European test of pesticide-leaching models: methodology and major recommendations. Agric Water Manag 44(1-3):1-19. doi:10.1016/S0378-3774(99)00081-5

Verma P, Singh P, George KV, Singh HV, Devotta S, Singh RN (2009) Uncertainty analysis of transport of water and pesticide in an unsaturated layered soil profile using fuzzy set theory. Appl Math Model 33(2):770-782. doi:10.1016/j.apm.2007.12.004

Vieux BE (1991) Geographic information systems and non-point source water quality and quantity modeling. Hydrol Process 5:101-113. doi:10.1002/hyp.3360050108

Wagener T, McIntyre N, Lees MJ, Wheater HS, Gupta HV (2003) Towards reduced uncertainty in conceptual rainfall-runoff mod- elling: dynamic identifiability analysis. Hydrol Process 17:455476. doi:10.1002/hyp. 1135

Wauchope RD (1978) The pesticide content of surface water draining from agricultural field: a review. J Environ Qual 7(4):459-471. doi:10.2134/jeq1978.00472425000700040001x

Wauchope RD, Ahuja LR, Arnold JG, Bingner R, Lowrance R, van Genuchten MT, Adams LD (2003) Software for pestmanagement science: computer models and databases from the United States Department of Agriculture-Agricultural Research Service. Pest Manag Sci 59:691-698. doi:10.1002/ps.682

Wauchope RD (2005) Pesticides and watershed-scale modelling: solutions for water quality management. J Agr Food Chem 53:8834-18834. doi:10.1021/jf051958m

Weill S, Mazzia A, Putti M, Paniconi C (2010) Coupling water flow and solute transport into a physically-based surface-subsurface hydrological model. Adv Wat Resour. doi:10.1016/j.adv watres.2010.10.001

Williams JB, (2002) Phytoremediation in Wetland Ecosystems: Progress, Problems, and Potential. Crit Rev Plant Sci 21(6): 607-635. doi:10.1080/0735-260291044386

Wohlfart J, Colin F, Assaghir Z, Bockstaller C (2010) Assessing the impact of the spatial arrangement of agricultural practices on pesticide runoff in small catchments: Combining hydrological modeling and supervised learning. Ecol Indic (4):826-839. doi:10.1016/j.ecolind.2010.01.004

Zadeh LA (1965) Fuzzy sets. Inform Control 8:338-353. doi:10.1016/ S0019-9958(65)90241-X

Zheng Y, Keller AA (2006) Understanding parameter sensitivity and its management implications in watershed-scale water quality modelling. Water Resour Res 42(5):W05402. doi:10.1029/ 2005WR004539 